\title{
A Lesser Bigotry? The UK Conservative Evangelical Response to Stephen Sizer's Antisemitism
}

\author{
James Mendelsohn and Bernard Nicholas Howard
}

\begin{abstract}
Jewish commentators frequently lament that antisemitism is seen as a "lesser bigotry" by those claiming to oppose racism. This article argues that the response of British conservative evangelical Christians to the antisemitic activity of Rev. Dr. Stephen Sizer is a prime example of this phenomenon. The article starts by defining conservative evangelicalism in the British context and explaining Dr. Sizer's position within it. It then describes his antisemitic conduct in detail. The article examines the disciplinary measures imposed upon Dr. Sizer by the Church of England, and it surveys the notoriety he earned in the UK media. The article then analyzes how Dr. Sizer's fellow British conservative evangelicals responded to his antisemitic activity, comparing this with their responses to other forms of racism. The article concludes by locating this episode within the context of other contemporary responses to antisemitism.
\end{abstract}

Keywords Stephen Sizer, Christianity, evangelicalism, conservative evangelicalism, racism, antizionism, antisemitism.

\section{INTRODUCTION}

In August 2020, against the backdrop of a global conversation on racism, the journalist Hadley Freeman lamented an apparent tolerance of antisemitism in both the United States and Britain. Only when the musician Wiley reportedly tweeted that Jews should be shot was there a consensus that this was genuinely antisemitic. Freeman asked: "Why is there only general agreement about antisemitism when a 41-year-old rapper tweets actual death threats? Antisemitism is, still, seen as a 'lesser' bigotry, which is why politicians and newspapers can dabble in it." 1

Freeman's complaint is common. A few weeks earlier, the Telegraph's Zoe Strimpel had asked, "Why does cancel culture never apply to anti-Semitism?"2 David Baddiel argues that antisemitism is simply, "The racism we think doesn't count." 3 Jan Shure has compared the differing reactions to Enid Blyton's racism (which targeted Black people) and the antisemitism of Roald Dahl, saying that until the responses match, "the UK Jewish community will be forced to conclude that anti-Semitism is not perceived as racism, and that anti-Jewish racism does not provoke the same revulsion (or action) as anti-Black racism." ${ }^{4}$ In his coruscating account of the case of Ronnie Fraser $v$ University and College Union (UCU), in which an English employment tribunal rejected complaints of antisemitism made against a trade union, David Hirsh wrote: "The UCU relied on arguments which it would have opposed sturdily in another context; the tribunal accepted arguments which it would not have accepted in another context." 5

Several voices, then, have suggested that antisemitism is seen as "a lesser bigotry" - by people professing opposition to racism. This 
article argues that the response of British conservative evangelical Christians to the antisemitic activity of Stephen Sizer is a prime example of this phenomenon.

\section{OUTLINE}

Section 1 seeks to define "conservative evangelicalism" in the British context.

Section 2 introduces readers to Rev. Dr. Stephen Sizer and his position within British conservative evangelicalism.

Section 3 describes Dr. Sizer's antisemitic conduct in detail.

Section 4 covers the Church of England "Clergy Discipline Measure" to which Dr. Sizer was subject between 2012 and 2013.

Section 5 surveys various disciplinary measures imposed upon Dr. Sizer by his bishop between 2015 and 2017.

Section 6 describes the notoriety that Dr. Sizer earned in the media.

Sections 7 and 8 form the centerpiece of our argument. In these sections, we analyze how various British conservative evangelical leaders and organizations responded to Dr. Sizer's antisemitic activity, and we compare this with their responses to other forms of racism.

Section 9 concludes our argument by locating this episode in the context of other contemporary responses to antisemitism.

\section{ZIONISM, ANTIZIONISM, AND ANTISEMITISM}

The core idea of Zionism is that Israel has the right to exist as a Jewish state. Advocates of antizionism hold either that Israel should not exist at all, or that it should not exist as a Jewishmajority state. In practice, as Howard Jacobson trenchantly observes, antizionists often frame such calls as mere "criticism."

We use the International Holocaust Remembrance Alliance (IHRA) Working Definition of Antisemitism, with all of its examples, as the basis for our arguments about antisemitism. ${ }^{7}$ One of its examples is "denying the Jewish people their right to selfdetermination, e.g., by claiming that the existence of a State of Israel is a racist endeavor." Therefore, depending on the overall context, an antizionist position (that is, denying Israel's right to exist, as opposed to specific criticisms of Israeli political or military actions) may be antisemitic.

Antisemitism often consists of "hallucinogenic fantasies" ${ }^{8}$ of Jewish power, conspiracy, and malice towards non-Jews. Whilst it is clearly distinctive, we nonetheless see antisemitism as closely related to other forms of racism, and argue that it should be opposed "both equally and on a similar basis." We also treat antisemitism as "an objective social phenomenon which cannot be defined simply by reference to the subjective feelings of individuals concerned." ${ }^{10}$ Save where people state their own intentions, we do not comment on these. We examine instead what people say and $d o$, and what the consequences are. ${ }^{11}$ This is particularly important when we consider Stephen Sizer's stated intentions, in Section 3 (b).

\section{OTHER TERMINOLOGY AND REFERENCES}

We define "evangelical" and the narrower term "conservative evangelical" in Section 1.

We capitalize the "B" in Black and the "W" in White. ${ }^{12}$

All Scriptural references (whether from the Tanakh or New Testament) are taken from the New International Version, 2011.

\section{What Is Conservative Evangelicalism?}

This article analyzes the response of a particular grouping within British Protestant Christianity-conservative evangelicals - to an individual within its midst accused of antisemitic activity. This section seeks to define that grouping for those unfamiliar with it. 
"Evangelicalism" derives from the Koine Greek evangelion, a frequently used word in the New Testament. Evangelion is usually translated "gospel" or simply "good news." Those who call themselves "evangelicals," therefore, are selfconsciously describing themselves as "good news people."

The concept of "good news" underlies evangelicalism's two main emphases: the Bible (the source of the good news); and salvation through faith in Jesus's atoning death (the content of the good news). Concerning the first emphasis, the late evangelical leader John Stott (1921-2011) explains, "Catholics emphasize the church, the magisterium and the role of tradition; liberals emphasize reason, conscience, and experience; evangelicals recognize tradition and reason, but as subordinate authorities to the only supreme authority: Scripture." Concerning the second emphasis, Stott says, "Catholics emphasize the priesthood and the sacraments as necessary to mediate salvation between God and us; liberals emphasize good works-individual and social righteousness-as at least contributing to our salvation; evangelicals affirm ministry, sacraments, and good works, but our focus is on the cross-what God has done in Christ for us." ${ }^{13}$

Unlike their American counterparts, British evangelicals are not perceived to support a particular political party. Nor-significantly for the purposes of this article-do they typically show the same strong support for Israel. In America, evangelicals generally do not belong to so-called "mainline Protestant" denominations, such as the Episcopal Church or the Presbyterian Church (USA); in England, however, there are numerous evangelicals within the established Church of England. This creates ambiguity regarding discipline. Sometimes Church of England evangelicals police themselves; ${ }^{14}$ yet they are also obliged to submit to the largely non-evangelical bishops and archbishops of the Church of England. The adjective denoting Church of England membership is "Anglican." There are also many non-Anglican evangelicals_-sometimes called Dissenters or Nonconformists - in groupings such as the Fellowship of Independent Evangelical Churches. ${ }^{15}$

Evangelicalism that is specifically "conservative" upholds and guards the two distinctive features discussed above. Other forms of evangelicalism are more willing to innovate in doctrine or religious experience. ${ }^{16}$

A widely respected organization within British conservative evangelicalism is the Gospel Partnerships network, in which Anglican and Nonconformist conservative evangelical churches cooperate regionally. ${ }^{17}$ Three significant Anglican conservative evangelical organizations are Anglican Mission in England (AMiE); ${ }^{18}$ ReNew; ${ }^{19}$ and Church Society, ${ }^{20}$ which merged with two similar organizations, Reform ${ }^{21}$ and the Fellowship of Word and Spirit, ${ }^{22}$ in 2018. ${ }^{23}$ Church Society runs an annual "Junior Anglican Evangelical Conference." ${ }^{24}$ Many British conservative evangelical Anglicans fraternize with their counterparts overseas through GAFCON (Global Anglican Future Conference), which was created in 2008, ${ }^{25}$ and which birthed AMiE, mentioned above. ${ }^{26}$ Christianity Explored Ministries promotes a widely used "seekers' course." ${ }^{27}$ The newspaper Evangelicals Now ${ }^{28}$ and the publisher Inter-Varsity Press (IVP) ${ }^{29}$ are influential. Oak Hill College in North London is a leading training institution. ${ }^{30} \mathrm{~A}$ key church is St. Helen's Bishopsgate in central London; ${ }^{31}$ a key individual is its senior minister, Rev. William Taylor, ${ }^{32}$ who has had leadership roles within several of the above organizations.

Conservative evangelicals' high view of Scripture should make them sensitive to how others perceive them, since the New Testament states that a church leader must "have a good reputation with outsiders." 33 This arguably exacerbates the failings discussed in this article, since the refusal of British conservative evangelicals to engage meaningfully with the Jewish community's concerns regarding Stephen Sizer represents an unwillingness to practice what they (literally) preach. We now consider Stephen Sizer himself. 


\section{Introducing Stephen Sizer}

Rev. Dr. Stephen Sizer is an ordained minister in the Church of England. Between 1997 and 2017, he was the vicar, or parish priest, of Christ Church Virginia Water (CCVW), in southern England. ${ }^{34}$ This church is now affiliated to the Surrey Gospel Partnership, ${ }^{35}$ a sub-region within the South East Gospel Partnership. ${ }^{36}$ Dr. Sizer was also, at various times, and among other roles, a Church Society board member; ${ }^{37}$ a member of Reform; ${ }^{38}$ a contributor to Evangelicals Now; ${ }^{39}$ a director of Biblica Europe, a Bible translation society; ${ }^{40}$ and an Advocate (that is, a promoter and trainer) for Christianity Explored Ministries. ${ }^{41}$ In short, he has been firmly planted within British conservative evangelicalism.

\section{Stephen Sizer's Output: From Antizionism to Antisemitism}

Dr. Sizer is best known for his opposition to Christian Zionism - that is, Christian support for Zionism and the state of Israel. This grew out of a concern for Palestinian Christians ${ }^{42}$ and was the topic of his $2002 \mathrm{PhD}$, completed under the auspices of Middlesex University and Oak Hill College. ${ }^{43}$ His doctoral thesis became the basis of two major books, both published by IVP: Christian Zionism: Roadmap to Armageddon? (2004) and Zion's Christian Soldiers? (2007). He has continued to write and speak prolifically about Christian Zionism. ${ }^{44}$ In this section, we first examine whether he truly accepts Israel's right to exist as a Jewish-majority state. We consider his stated intentions, including that of repudiating antisemitism. We then explore various occasions when his words and actions have nonetheless demonstrated outright antisemitism.

\section{(a) Antizionism: Does Stephen Sizer Accept Israel's Right to Exist?}

In Zion's Christian Soldiers? Dr. Sizer states that he "defend[s] the right of Israel to exist within borders recognized by the international community and agreed with her neighbours. ${ }^{\prime 45} \mathrm{He}$ has written to one of the authors of this article, "I respect, accept and defend the right of Israel to exist. Period.”46 Such words seemingly represent a straightforward commitment to Israel's survival. Other statements, however, suggest otherwise.

In Christian Zionism, Dr. Sizer says that "endemic racism" is "intrinsic to Zionism. ${ }^{77} \mathrm{He}$ characterizes Zionism as "ethnic exclusivism," and refers positively to the infamous 1975 United Nations Resolution 3379, which equated Zionism with racism. ${ }^{48} \mathrm{He}$ entirely overlooks the Resolution's background, notably the influence of Ugandan dictator Idi Amin. In 1972, Amin praised the Holocaust and proposed erecting a statue to Hitler in Uganda. Three years later, he denounced the "Zionist-American conspiracy" before the UN General Assembly and called for Israel's "extinction"- to warm applause from the Soviet and Arab blocs. The "Zionism is racism" motion was passed shortly afterwards, described by the historian Paul Johnson as the "greatest triumph" of the "professional anti-Semites of the Soviet and Arab publicity machines." ${ }^{49}$ Dr. Sizer omits this background, and appears to decry the US-influenced revocation of the Resolution in $1991 .^{50}$

In the same section of Christian Zionism, Dr. Sizer refers approvingly to the denunciation of Israel at the UN World Conference Against Racism in 2001, which has been described as "a largely successful attempt to construct Zionism as the key form of racism on the planet." ${ }^{51}$ This culminated in the circulation of literature glorifying Hitler and a march on a local Jewish club. ${ }^{52}$ This background, once again, is entirely omitted by Dr. Sizer. ${ }^{53}$

Dr. Sizer quotes with approval the following extract from the Conference's declaration: "We recognize the right of refugees to return voluntarily to their homes and properties in dignity and safety, and urge all States to facilitate such return." ${ }^{54}$

The "right of return" of millions of descendants of the 1948 Palestinian refugees to pre-1967 Israel has long been recognized as "a euphemism for eliminating the Jewish state 
altogether, in this case through demographic subversion." ${ }^{5}$ For Dr. Sizer to quote the above extract approvingly — without any background, qualification, or explanation-appears to indicate his openness to that outcome. ${ }^{56}$

In October 2010, Dr. Sizer blogged in support of the former White House correspondent Helen Thomas. Thomas had resigned after telling a rabbi that Jews should "get the hell out of Palestine" and "go home" to "Poland, Germany ... America and everywhere else." Her choice of words was significant. If she had simply had the West Bank settlers in mind, she would have told them to return to pre-1967 Israel. Poland and Germany, however, were, of course, places from which Holocaust survivors had departed for the Middle East after World War II. Therefore, she was not simply calling for the dismantling of the West Bank settlements, but for the dismantling of the whole Israeli state and the dispersion of its Jewish population. In his blogpost, Dr. Sizer offered Thomas unqualified support. He praised her as "one gutsy 90 year old lady to take on the Israel Lobby" and, in response to her comments, said, "Bring it on." 58

In short, several of Dr. Sizer's statements call into question whether he truly accepts Israel's right to exist as a Jewish-majority state.

Dr. Sizer insists that "Anti-Zionism is not the same thing as anti-Semitism, despite attempts to broaden the definition." 59 According to the IHRA Working Definition of Antisemitism, however, "contemporary examples of antisemitism . . . could, taking into account the overall context, include ... [d] enying the Jewish people their right to self-determination, e.g. by claiming that the existence of a State of Israel is a racist endeavour." By this yardstick alone, the underlying implication of Dr. Sizer's work is arguably antisemitic.

Numerous other statements and actions, both in his books and elsewhere, go considerably further, demonstrating a mixture of explicit antisemitism, implicit antisemitism, and complicity with antisemites. Before considering these, however, it is worth noting that Dr. Sizer presents himself as an opponent of antisemitism.

\section{(b) Stephen Sizer's Stated Intentions}

In the conclusion to his $\mathrm{PhD}$ thesis, Dr. Sizer writes, "This research has sought to reject both anti-Semitism as well as nationalistic Zionism." 60 In the conclusion to Christian Zionism, he claims, "This study has sought to repudiate not only anti-Semitism but also nationalistic Zionism." ${ }^{61}$ Near the start of Zion's Christian Soldiers? Dr. Sizer condemns antisemitism as a form of racism: "It is true that at various times in the past, churches and church leaders have tolerated or incited anti-Semitism and even attacks on Jewish people. Racism is a sin and without excuse. Anti-Semitism must be repudiated unequivocally." 62

However, Dr. Sizer's disclaimers do not automatically absolve him. Antisemitism is "an objective social phenomenon which cannot be defined simply by reference to the subjective feelings of individuals concerned." ${ }^{63}$ It is "not simply a matter of what is inside people's heads . . . antisemitism is also, and primarily, a matter of what people do and of what consequences their actions have." ${ }^{34}$ One consequence of Dr. Sizer's actions is that his writing is included on a list titled "101 Books Every White Man Must Read" on a White supremacist website. ${ }^{65}$ Another is that his writing is listed on the antisemitic website The Revisionist Clarion, alongside endorsements of David Irving. ${ }^{66} \mathrm{We}$ therefore need to look at what he has actually said and done.

\section{(c) Beyond Antizionism: An Incomplete List of Stephen Sizer's Antisemitic Activity}

In 1996, Dr. Sizer wrote, "with the US elections a few weeks away, neither [Bob] Dole nor [Bill] Clinton will dare upset the Jewish lobby." ${ }^{67}$ Suggesting that American politics is controlled by an all-powerful Jewish lobby is a longestablished antisemitic trope. ${ }^{68}$ 
In a footnote in his 2004 book Christian Zionism: Roadmap to Armageddon?, Dr. Sizer uncritically refers his readers to an article alleging Israeli complicity in the $9 / 11$ terrorist attacks on the USA. ${ }^{69}$ In the same book, Dr. Sizer claims that Zionist leaders in the 1930s collaborated with the Nazis. ${ }^{70}$ Former London mayor Ken Livingstone was suspended by the UK Labour Party in 2017 for making the same claim. ${ }^{71}$ Elsewhere in the book, in order to support his critique of Christian Zionism, Dr. Sizer cites approvingly a commentator called Dale Crowley. Crowley was connected with the American far right and the world of Holocaust denial. ${ }^{72}$ Dr. Sizer describes him simply as a "religious broadcaster." ${ }^{73}$ Dr. Sizer earlier referred to Crowley in the same way in his $\mathrm{PhD}$ dissertation. ${ }^{74}$

In 2006, Dr. Sizer wrote a letter to Independent ${ }^{75}$ responding to the then Chief Rabbi's criticism of the Church of England for voting to divest from Caterpillar (due to Caterpillar's ties to Israel). ${ }^{76}$ In his letter, Dr. Sizer labelled opponents of the divestment vote, such as the Chief Rabbi, "the people in the shadows"-language connoting a secret, sinister conspiracy. ${ }^{77} \mathrm{He}$ also wrote that the Church of England's General Synod "refuse[d] to be intimidated by those who like Chicken Little cry 'anti-Semitism' whenever Israeli human rights abuses in the occupied territories are mentioned." In this early example of the so-called "Livingstone Formulation," 78 Dr. Sizer alleged that an accusation of antisemitism had been made in bad faith in order to silence critics of Israel.

Also in 2006, Dr. Sizer took a photograph of Israel's security barrier. He captioned it, "Arbeit macht frei" (Image 1) ${ }^{79}$ —an obvious allusion to Auschwitz. He thereby downplayed the significance of the Holocaust by equating Israel's policies towards the Palestinians with the systematic, industrialized murder of two-thirds of European Jewry by the Nazis. This was also an example of what is known as "Holocaust inversion," which casts Israel as the "new" Nazis.
In a 2008 interview on Iran's Press TV, Dr. Sizer again downplayed the significance of the Holocaust, saying: "The Holocaust has been perpetuated over the last 40 or 50 years-it's the Palestinians who are going through their Nakba now." ${ }^{81}$

In 2010, Hillary Clinton rebuked Israel for deciding to build new settlements in East Jerusalem. Dr. Sizer blogged about this episode. His heading included the words, "Payback for Monica?" 82 This was an allusion to Monica Lewinsky, the Jewish White House intern with whom Hillary's husband, Bill, had committed adultery. Dr. Sizer therefore highlighted Lewinsky's Jewishness in the pejorative context of an adulterous affair. By connecting Lewinsky (a non-Israeli American citizen) to Hillary Clinton's criticisms of the Israeli government, Dr. Sizer nullified the distinction between Jewishness and Israeli policy that elsewhere he insisted should be upheld (see, for example, his "Chicken Little" comment quoted above).

In March 2010, Dr. Sizer posted a gallery of photographs of Israeli soldiers operating near Bethlehem in the West Bank. He titled it, "Herod's Soldier's [sic] Operating in Bethlehem today," combining two antisemitic motifs - that Jews are both Christ-killers and child-killers (Image 2)..$^{83}$

In October 2010, Dr. Sizer blogged in support of Helen Thomas, as noted above. ${ }^{84}$ To our earlier observations we may add the following. He titled that blogpost, "Helen Thomas: You cannot criticize Israel in the US and survive." He praised Thomas as "one gutsy 90 year old lady to take on the Israel Lobby." 85 In addition to equating a call for the dismantling of the state of Israel with mere "criticism," Dr. Sizer employed the antisemitic trope that the "Israel Lobby" exerts not just political influence but malevolent, destructive power.

In March 2011, Dr. Sizer reproduced an internet rumor that Saif Gaddafi, son of the late Libyan dictator Muammar, had visited Israel in order to buy weapons to suppress the Libyan 


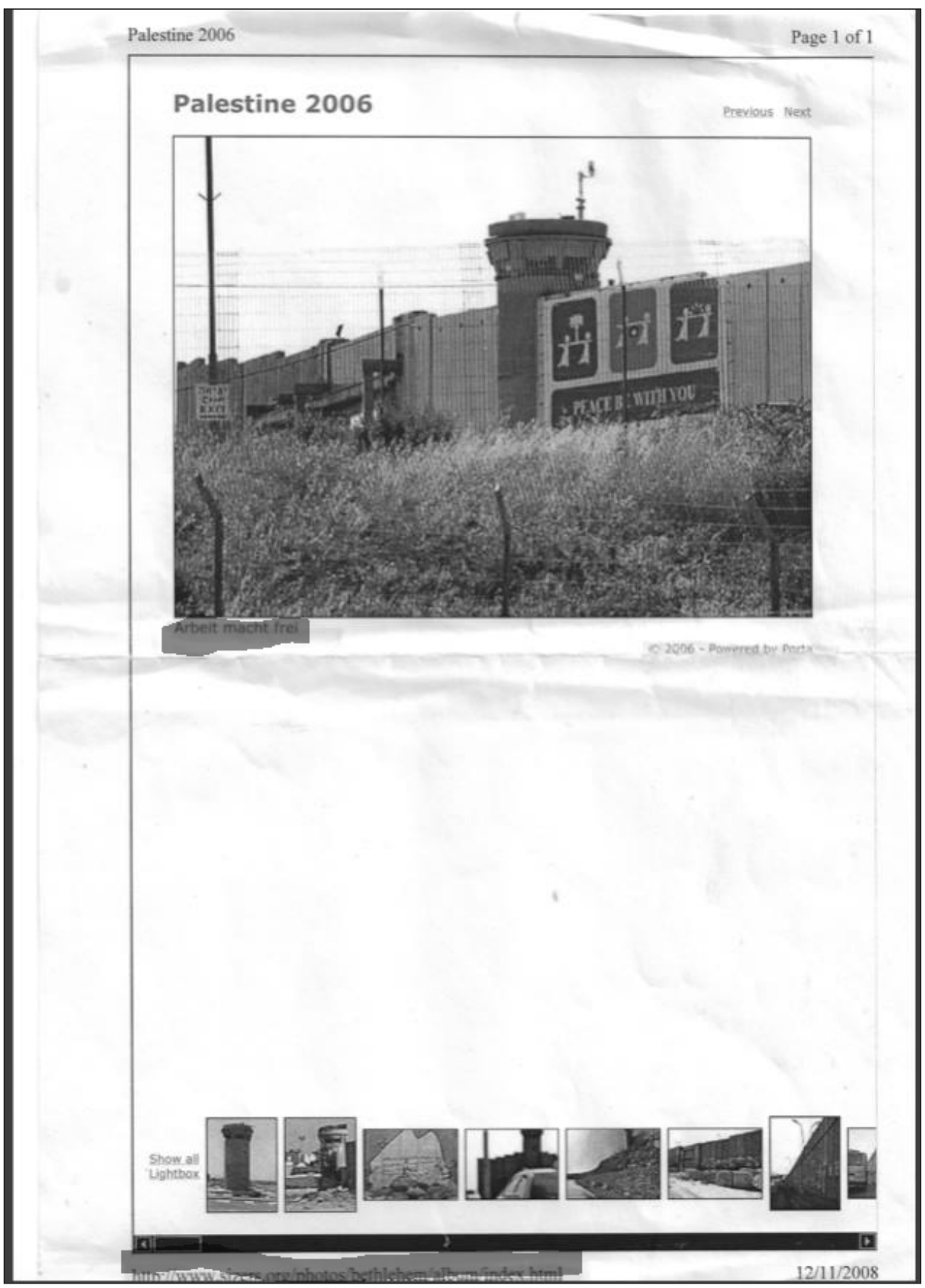

IMAGE 1: Stephen Sizer's photograph of Israel's security barrier, captioned "Arbeit macht frei" (highlighting added). 


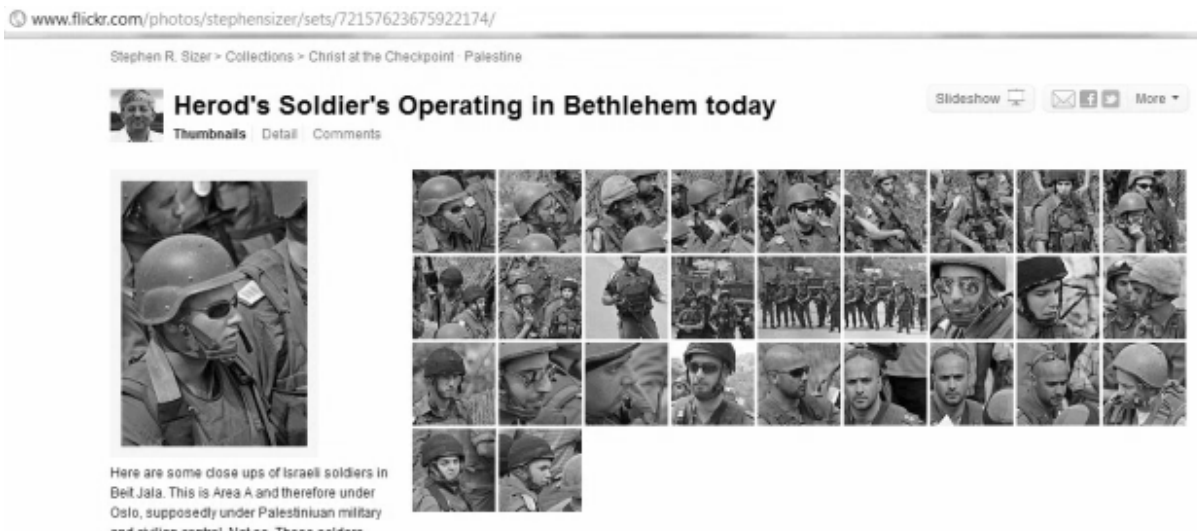

IMAGE 2: Gallery of photographs of Israeli soldiers.

uprising. Dr. Sizer tied this to the Gaddafis' supposed Jewish heritage, initially writing:

It should come as no surprise that "Saif al-Islam, son of Colonel Muammar Gaddafi" made a surprise visit to Israel last week to buy more weapons for his dad.

He goes to Israel regularly because, according to a senior Middle East Ecclesiastical source, both his mother and aunt are Jewish and live in Israel. Blood is indeed thicker than water. Perhaps this is why the US is reluctant to impose a "no-fly" zone over Libya. ${ }^{86}$

Dr. Sizer thereby appeared to link Israel, the Gaddafis, the United States, and the violent oppression of Libyan civilians, all on the basis of (supposed) Jewish blood.

In June 2011, in an interview on Malaysian TV, Dr. Sizer said,

The Far Right in Britain is forming an alliance with Zionists because their common enemy are the Muslims, and it's ironic that the very people who favoured the work of Hitler are now working with the Zionists, the English Defence League for example, against the Muslims because they view them as a threat. ${ }^{87}$

A year earlier, a survey had found that a strong majority of British Jews categorized themselves as "Zionists," saying that Israel was either "central" or "important" to their Jewish identities. ${ }^{88}$ Yet there is no evidence of any widespread sympathy among British Jews for the English Defence League, ${ }^{89}$ nor (of course) for anyone openly supportive of "the work of Hitler." Dr. Sizer's words on Malaysian TV about "the Zionists" can therefore be seen as a false negative generalization about British Jews. In the same interview, Dr. Sizer explained strong support for Israel in the US Congress by claiming that "the Israel Lobby" had "bought every single one of those politicians." He also said that American politicians "won't dare" criticize Israel because "the Israel Lobby will fund their competitors, their opponents, and they'll be out of office." 90

On the same trip to Malaysia, Dr. Sizer interviewed an activist in an organization called "Viva Palestina Malaysia." The activist advocated boycotting four multinational companiesMcDonald's, Coca-Cola, L'Oréal and Nestlé-on the basis that they "channel their profits to the Zionist agenda." Dr. Sizer did not challenge this modern formulation of the antisemitic trope of Jewish control of the global economy. Indeed, he helped the activist find his words, and at one point appeared to indicate his agreement. $\mathrm{He}$ then uploaded the interview to his own Vimeo site, where (as of the date of writing) it remains. ${ }^{91}$ 
In July 2011, the Arab-Israeli Islamist Raed Salah evaded a ban on entering Britain..$^{92} \mathrm{He}$ was later arrested. ${ }^{93}$ Salah had previously delivered a notorious sermon in East Jerusalem in which he claimed that Jews used children's blood to make matzah-a clear re-articulation of the medieval blood libel. ${ }^{94}$ Following Salah's detention, however, Dr. Sizer gave him unqualified public support, describing him as a "political prisoner," ascribing his arrest to "the influence of the Israel Lobby," and treating him to a meal in a London restaurant. ${ }^{95}$ Associating with Salah is not necessarily objectionable in itself. (Evangelical Christians believe in the value of visiting prisoners.) However, given that Dr. Sizer did so without any attempt to distance himself from Salah's well-known antisemitic record, and given that Dr. Sizer had by then gained his own reputation for antisemitism, his public association with Salah should be regarded as a grievous act of antisemitic antagonism.

Between July 2011 and June 2012, Dr. Sizer posted links on his blog and Facebook page to several explicitly antisemitic websites, including The Palestine Telegraph, ${ }^{96}$ The Ugly Truth, ${ }^{97}$ and Veterans Today. ${ }^{98}$ When challenged, he gave unpersuasive explanations. ${ }^{99}$

In July 2012, Dr. Sizer hosted an event in London on behalf of the Islamic Human Rights Commission (IHRC), ${ }^{100}$ an organization which had previously implored Israel's neighbors to "release their armies to burn that land." 101

In March 2013, Dr. Sizer posted an article on his Facebook page by former British diplomat Craig Murray. The article argued that Palestinian students had chosen the wrong target when they physically attacked another British diplomat, Sir Vincent Fean. ${ }^{102}$ A person named Salim Nazzal responded, "You may be right about the man. But if Britain did not import to Palestine those professional east europian $[$ sic $]$ murderers we would be now living in peace in our home." Rather than challenging this characterization of Israeli Jews as alien, murderous interlopers to the Middle East, Dr. Sizer replied, "I agree with you Salim — that is why I wrote the book Christian Zionism." 103
In autumn of 2014, Dr. Sizer delivered a talk titled "The Israeli Lobby in England" at the antisemitic "Second New Horizon Conference" in Iran, thereby giving unjustified legitimacy to the conference through his presence as a Church of England vicar on its platform. He was also a member of a panel on "The Mechanisms of Action of the Israeli Lobby and their Effects in Western Capitals.” The Community Security Trust commented that his presence at that conference as an Anglican vicar was "utterly shameful." 104

In January 2015, Dr. Sizer revisited the antisemitic myth of Israeli involvement in 9/11, posting an article titled "9/11: Israel Did It" on his Facebook page. His source was the antisemitic conspiracy theory website WikiSpooks. ${ }^{105}$ Following that Facebook post, which attracted national attention (see below, Section 6), the Church of England imposed heavy restrictions on Dr. Sizer's activity (discussed in Section 5). His antisemitic conduct subsequently became less egregious, without ceasing entirely. ${ }^{106}$

\section{(d) Analysis}

What is striking about the above list is how little of it is distinctively Christian. Although it has a few theological elements (notably the reference to "Herod's Soldiers"), most of the examples have no clear connection to Christianity. ${ }^{107}$ They could be produced by someone of a different faith or none. They include several common contemporary antisemitic tropes: conspiracy theories centered on the supposed malign influence and financial power of the state of Israel and its supposed lobby elsewhere; linking diaspora Jews (real or imagined) to Israel's misdeeds (real or imagined); implicitly calling for Israel's dismantling; "Holocaust inversion"; and the Livingstone Formulation.

Rather than demonstrating a specifically Christian form of contemporary antisemitism, therefore, Dr. Sizer instead represents a textbook example of "antisemitism amongst people who believe that they strongly oppose antisemitism." 108 The examples above do not represent 
the type of antisemitism accompanied by swastikas and straight-armed salutes. Rather, they represent the kind of contemporary left antisemitism which is linked to hostility to Israel, but which "diverges radically from rational or legitimate criticism of Israeli policy." 109 They represent the kind of antisemitism which is, mainly, "polite, civil and sophisticated ... the antisemitism of good people." ${ }^{110}$ And what better example of a "good person" than a polite, softly spoken Anglican vicar, carrying a doctorate and expressing concern for Palestinian Christians?

The substance, therefore, of Dr. Sizer's antisemitic activity is unremarkable. Of greater interest and wider significance is how his fellow British conservative evangelicals responded. This is considered shortly. First, we survey the respective responses of the (largely non-evangelical) Anglican hierarchy and the British media.

\section{Church of England "Clergy Discipline Measure": 2012-2013}

In October 2012, the Board of Deputies of British Jews formally complained to the Church of England about Dr. Sizer. ${ }^{111}$ The complaint was backed by the Community Security Trust and the Jewish Leadership Council. ${ }^{12}$ It triggered a "Clergy Discipline Measure" (CDM). This concluded with a conciliation meeting in October 2013, where Dr. Sizer agreed to have his online activity monitored. ${ }^{113}$

Rather than retracting its complaint against Dr. Sizer, the Board of Deputies restated it when the conciliation agreement was announced. The Board's vice-President, Jonathan Arkush, explained that the complaint had been lodged because of Dr. Sizer's "statements that most of the [Jewish] community found utterly offensive, to the point of crossing the line into antisemitism, and his pattern of posting links to racist and antisemitic websites where scurrilous statements against Jews and others are published." ${ }^{114}$ The Board's representatives did not change their minds about the nature of Dr. Sizer's conduct; they were simply satisfied that his online activity would from then on be closely monitored.

Significantly, the CDM never led to any formal verdict from the Church of England on the rights and wrongs of Dr. Sizer's conduct. This was predictable. The Church of England seeks to keep diverse groups within the same tent and typically avoids the kind of disciplinary action that might disturb the fragile peace. In one totemic example, the Church of England declined to act against Rev. Don Cupitt after he effectively denied the existence of God in his 1980 book Taking Leave of God. ${ }^{115}$ It is therefore unsurprising that the Church of England was satisfied with a purely pragmatic resolution to the Board of Deputies' complaint against Dr. Sizer.

However, moral questions remained: was Dr. Sizer guilty of antisemitic activity, as the Board continued to allege; and, if so, how should Dr. Sizer's various colleagues respond? Such questions ought to have troubled Dr. Sizer's fellow conservative evangelical leaders, given their distinctive commitment to Scripture and its high ethical standards. Yet, as will be seen in Sections 7 and 8, their engagement was minimal and superficial. The questions only intensified after further disciplinary measures were taken against Dr. Sizer in 2015-2017.

\section{Public Rebuke, Social Media Ban, and Preaching Ban: 2015-2017 and Beyond}

In January 2015, as mentioned above, Dr. Sizer posted a link on his Facebook page to an article accusing Israel of complicity in 9/11. ${ }^{116}$ This prompted a fresh complaint by the Board of Deputies. The Board's vice-president, Jonathan Arkush, said, "Posting, and giving approval to, an article which in effect accuses Jews of responsibility for the $9 / 11$ atrocity is unquestionably anti-Semitic, just as it is beyond absurd." 117 When contacted by the Jewish News, Dr. Sizer asked for evidence refuting the allegations, saying that he was "encouraging research and debate." 118 
On February 9, 2015, the new Bishop of Guildford, Rt. Rev. Andrew Watson-not a conservative evangelical ${ }^{119}$ — publicly rebuked Dr. Sizer, saying:

I do not believe that [Dr. Sizer's] motives are anti-Semitic; but I have concluded that, at the very least, he has demonstrated appallingly poor judgment in the material he has chosen to disseminate, particularly via social media, some of which is clearly anti-Semitic.

By associating with or promoting subject matter, which is either ambiguous in its motivation, or (worse still) openly racist, he has crossed a serious line. I regard these actions as indefensible. ${ }^{120}$

The bishop revealed that Dr. Sizer had undertaken to forego social media for six months, and to "refrain entirely from writing or speaking on any theme that relates, either directly or indirectly, to the current situation in the Middle East or to its historical backdrop." 121 This prohibition was to include attendance at, or participation in, any conferences addressing such themes; all related writing, tweeting, blogging, emailing, preaching, and teaching, whether formal or informal; posting links to other sites; and equipping others to act in his place. Dr. Sizer promised that should he breach either the letter or spirit of this undertaking, he would offer his resignation to the bishop. ${ }^{122}$ The Bishop of Guildford said that, "most importantly of all," he was "hugely sorry for the hurt which has been caused to members of the Jewish community" by Dr. Sizer's conduct. ${ }^{123}$

In October 2016, Dr. Sizer attended a meeting in Parliament about Israel and Palestine, and wrote about it online, violating his undertaking. He was warned that any repeat would trigger the immediate end of his tenure. ${ }^{124}$ But in early 2017, he wrote on Facebook in support of Swedish politician Margot Wallström's stance on Saudi Arabia. ${ }^{125}$ (Wallström had previously been accused of invoking the antisemitic blood libel for apparently linking the November 2015 Islamist atrocities in Paris to the suffering of the Palestinians.) $)^{126}$ The Bishop of Guildford required Dr. Sizer to cease immediately all preaching, teaching, leading of services, and social media activity. He was, however, allowed to lead Easter services to enable his parishioners to wish him goodbye before his retirement from parish ministry that Easter. ${ }^{127}$

Since we do not analyze the Church of England's response to Dr. Sizer elsewhere in this article, it is worth making some brief remarks at this point. In the opinion of the authors, while the Church of England's disciplining of Dr. Sizer from 2015 to 2017 was not insignificant, it was badly inadequate, and it was very poorly enforced when its terms were breached.

Dr. Sizer now directs a charity called Peacemaker Trust. ${ }^{128}$ Since leaving parish ministry, free from a bishop's oversight, his antisemitic activity has continued. Appearing on Press TV in 2018, Dr. Sizer initially said, "the Jewish community ... is paranoid about Jeremy Corbyn becoming Prime Minister," thereby attributing an irrational, negative attitude to an entire ethnic group. As Adam Holland observed, Dr. Sizer “corrected himself to say 'Zionist,' but his intended target was clear." ${ }^{29}$

Later that year, Dr. Sizer posted a link on Facebook to an article titled, "Is Israel's Hidden Hand Behind the Attacks on Jeremy Corbyn?"-a classic expression of the antisemitic myth that Jews control the global media. Dr. Sizer added the comment: "You would have to be blind as a bat not to see their hands." 130

Most recently, in February 2021, Dr. Sizer published a post on his Facebook page suggesting that Israel is a "terrorist state"-the kind of extreme antizionist rhetoric that serves no purpose other than to stir up hatred against the world's only Jewish-majority state. ${ }^{131}$ In the same post Dr. Sizer promoted an antizionist seminar chaired by Mick Napier, who was convicted in 2017 of aggravated trespass (a criminal offense) for his role in a 2014 protest at an Israeli-owned cosmetics store in Glasgow. ${ }^{132}$ 


\section{National Notoriety}

Dr. Sizer's activity has been reported in numerous outlets, including: the BBC website; ${ }^{133}$ the political blog Harry's Place; ${ }^{134}$ the Spectator, ${ }^{135}$ Standpoint, ${ }^{136}$ and New Statesman; ${ }^{137}$ The Times (both in news items and an editorial); ${ }^{138}$ the Telegraph, ${ }^{139}$ the Mirror, ${ }^{140}$ the Daily Mail, ${ }^{141}$ the Independent, ${ }^{142}$ and the Guardian. ${ }^{143}$ His activity formed part of the backdrop to both the $2017^{144}$ and $2019^{145}$ UK General Elections, owing to the earlier defense of Dr. Sizer by Jeremy Corbyn. ${ }^{146}$

Dr. Sizer's activity and the Jewish community's response were reported in the Jewish Chronicle ${ }^{147}$ and the Jewish News. ${ }^{148}$ There were also reports in Christian outlets including the Church Times; ${ }^{149}$ the Church of England Newspaper; ${ }^{150}$ and the widely read Archbishop Cranmer blog. ${ }^{151}$ The limited coverage by Evangelicals Now is considered in Section 7 (a) below.

In short, Dr. Sizer was unarguably the single most controversial conservative evangelical Anglican vicar between 2012 and 2017. We will now consider how his fellow British conservative evangelicals responded.

\section{An Overview of the Conservative Evangelical Response}

When Dr. Sizer was eventually disciplined, it was by the Church of England. Yet he was positioned firmly within conservative evangelicalism, a movement existing both inside and outside the Church of England that is distinct from the Anglican hierarchy. ${ }^{152}$ This section outlines the response of various conservative evangelical voices during the years both before and after Dr. Sizer's retirement from parish ministry in 2017. Where those voices have openly stated their position on racism, we include those statements. We also engage in some preliminary analysis, while leaving more general assessment to the following section.

\section{(a) Evangelicals Now}

In 2011, the authors asked the newspaper Evangelicals Now (EN) to publish a letter criticizing Dr. Sizer's conduct, ${ }^{153}$ suggesting this could be published alongside a response from Dr. Sizer. A comparison was drawn with EN's publication of articles critical of Steve Chalke, a Christian minister who had renounced core Christian doctrines. ${ }^{154}$ EN's board declined, saying:

We felt that it is a very different situation to that of the Steve Chalke controversy and ... should not be something which EN takes up. In the case of Steve Chalke, he was making a direct attack on central truths of the gospel ... and as such had to be countered. This is not the case with Stephen Sizer. ${ }^{155}$

EN did later report on Dr. Sizer's 2015 social media and preaching ban, ${ }^{156}$ and on the 2016 withdrawal of his books by IVP. ${ }^{157}$ These reports, however, were brief. They mentioned that Dr. Sizer had posted material alleging Israeli complicity in $9 / 11$, but did not explain why doing so would be antisemitic; they included Dr. Sizer's denials of wrongdoing, but did not mention his numerous prior offences. The reports were therefore of extremely limited value in enabling readers to reach an informed view of Dr. Sizer's conduct-something EN has sought to do in other high-profile controversies involving conservative evangelicals. ${ }^{158}$ Nor did EN outline Dr. Sizer's ties to numerous evangelical organizations, effectively protecting those organizations from criticism for their continued association with him. In contrast, the Jewish Chronicle published fifty-one articles on Dr. Sizer between 2012 and $2020 . .^{159}$

EN's initial pushback against the authors and its negligible later reporting had the effect of shielding Dr. Sizer from scrutiny. EN therefore bears considerable responsibility for the general lack of evangelical concern about Dr. Sizer. However, when other evangelical boards were approached directly with information about Dr. Sizer, they too displayed the same reluctance to act. 


\section{(b) South East Gospel Partnership}

The South East Gospel Partnership (SEGP) is a group of churches that collaborate on activities such as training leaders and planting new congregations. ${ }^{160}$ There are similar regional partnerships across the UK. ${ }^{161}$

In early 2012, the Steering Committee of the SEGP was asked to consider excluding Christ Church Virginia Water from the partnership, for as long as Dr. Sizer remained its vicar. The SEGP's chairman, Rev. William Taylor, initially claimed that the partnership had no "means of discipline." ${ }^{62}$ However, he did then pursue a limited investigation into Dr. Sizer "on behalf of the Gospel Partnerships,"163 thereby indicating not only that the SEGP could act if necessary, but also that the SEGP would be representing the entire network of Gospel Partnerships.

This investigation ended with an email from Rev. Taylor to the complainant stating that he saw "no justifiable grounds for breaking gospel partnership with Stephen." ${ }^{164}$ Rev. Taylor also told the complainant that he had spoken to his employer-an Australian pastor in New York who had no knowledge of the issues involving Dr. Sizer. This was understood by the complainant to be an attempt by Rev. Taylor to intimidate him into dropping his requests for action against Dr. Sizer's church. In the same email, Rev. Taylor informed the complainant that he had forwarded their entire correspondence to Dr. Sizer himselfcorrespondence that included highly sensitive information sent to the complainant by a former member of Christ Church Virginia Water. It had been explained to Rev. Taylor that this information came with a request for the strictest confidentiality.

In 2016, the SEGP had a golden opportunity to change its position: Rev. Angus MacLeay, the widely respected Senior Minister of a large affiliated church, approached the SEGP's Steering Committee with a request for action to be taken against Dr. Sizer. ${ }^{165}$ That request explained to the
Steering Committee why Dr. Sizer's words and actions were antisemitic (reiterating earlier explanations). Yet the Steering Committee simply acknowledged receipt of Rev. MacLeay's correspondence, without offering any substantive response. ${ }^{166}$

The SEGP maintained its support for Dr. Sizer right up until his retirement in 2017, upholding "gospel partnership" (that is, friendly working relations) with him even during the final months of his incumbency, when he was banned by his bishop from all preaching, teaching, leading of services, and social media activity.

What should the SEGP have done? While the Gospel Partnerships are loose associations without formally constituted disciplinary processes, one can easily imagine situations where a partner church would be excluded. If Dr. Sizer had begun preaching against central evangelical doctrines, or engaged in another kind of racist activity, or displayed any other serious moral failing, the SEGP committee would surely have found a way to remove his church from their partnership. In December 2020, Rev. William Taylor's church (St Helen's Bishopsgate, London) announced that it was "no longer able to remain in gospel partnership" with the Church of England's House of Bishops due to differences over sexual ethics. ${ }^{167}$ Under Rev. Taylor's leadership, however, the SEGP failed to take the equivalent action when the issue was antisemitism.

Several leaders within the SEGP and the wider Gospel Partnerships movement have expressed opposition to racism. In June 2020, Rev. Richard Coekin, who serves on the leadership committee of the London Gospel Partnership (an SEGP sub-region), published an article titled George Floyd: A White Christian's Response. He wrote,

Becoming more inclusive requires me as a church leader to engage and empathise with the experience of racism in its many forms among my own church family and network in London. 
In truth, this is really a conversation we have only just properly begun. After listening, I need to take advice- to allow the voice of those who have hitherto been ignored to actually influence my decisions. ${ }^{168}$

Similarly, John Stevens, the National Director of the Fellowship of Independent Evangelical Churches (FIEC), who describes himself as "deeply involved in the development of these [Gospel] Partnerships," ${ }^{169}$ writes,

I can't begin to understand the experience and anguish of those who suffer from systemic racial prejudice, to which I no doubt inadvertently contribute. So, it is absolutely essential that we listen and hear the voice of those who can tell of their experience of prejudice, inequality and oppression. Only as we do that can we avoid speaking in crass or patronising ways, gain some greater measure of empathy and hear what might be done to make things better. ${ }^{170}$

A third example comes from the Twitter account of St. Helen's Bishopsgate, whose Rector is Rev. William Taylor. On June 24, 2020, a St. Helen's tweet directly addressed the issues of racism raised by the Black Lives Matter organization (Image 3). ${ }^{171}$

These admirable ideals have yet to prompt any discernible action regarding Dr. Sizer's antisemitic conduct. The need for action continues despite Dr. Sizer's retirement, because his former congregation, Christ Church Virginia Water, remains unrepentantly supportive of Dr. Sizer. ${ }^{172}$ Christ Church Virginia Water belongs to the Surrey Gospel Partnership, a sub-region of the SEGP. Its standing within the SEGP has never been publicly challenged by any major figure within the Gospel Partnerships movement.

The authors consider that Christ Church Virginia Water would not have retained its position within the Gospel Partnerships movement if the racist activity of its former vicar had targeted Black people. The ongoing refusal of the SEGP to act against Christ Church Virginia Water therefore bears out the "lesser bigotry" thesis of this article. For the Gospel Partnerships movement, antisemitism is the racism that does not count enough to necessitate action.

John Stevens tweeted about the failure of British evangelicals to act against Dr. Sizer on June 4, 2020, claiming, "Stephen Sizer was subject to an inquiry and subsequent disciplinary measures by his diocese, who were the competent disciplinary body." ${ }^{173}$ This is a reference to the Clergy Discipline Measure (CDM) discussed above. ${ }^{174}$ The excuse proposed by Rev. Stevens might justify evangelical inactivity between October 2012 and October 2013, while the CDM was in process. However, it does not explain the total absence of action before October 2012 - a time when the SEGP was being pressed to act. Nor does it explain evangelical inactivity between October 2013, when the CDM ended without any moral verdict, and February 2015, when Guildford Diocese disciplined Dr. Sizer for his $9 / 11$ post. Nor does it explain evangelical inactivity after February 2015, when Dr. Sizer twice breached his agreement with the Bishop of Guildford and yet his church retained its position within the SEGP. Nor can it account for evangelical inactivity since Dr. Sizer's retirement in 2017, during which time Christ Church 
Virginia Water has kept its place within the SEGP despite its ongoing ties with its former vicar and its refusal to apologize for his conduct. ${ }^{175}$

Furthermore, the notion that evangelicals are bound by the disciplinary decisions of the Anglican hierarchy, implied by Rev. Stevens in the above-quoted tweet, would immediately be questioned by most evangelicals. Rev. Stevens has himself criticized the Anglican hierarchy several times. ${ }^{176}$

\section{(c) Christianity Explored Ministries}

In 2014, the authors asked the board of Christianity Explored Ministries (CEM) to remove Dr. Sizer from his position as an Advocate for its seekers' course, on the grounds of both antisemitism and dishonesty. (The latter charge relates to Dr. Sizer's long delay in removing his link to the antisemitic website, “The Ugly Truth." Dr. Sizer falsely claimed not to have known the racist nature of that website until he was contacted by the Jewish Chronicle, at which point he removed the link. In reality, he had received an email from his bishop weeks beforehand, rebuking him for the link because of the website's racism. Dr. Sizer had responded promptly to the bishop's email, promising to take more care in the future.) ${ }^{177}$ The board was sent a document providing evidence for both charges. ${ }^{178}$ CEM's working relationship with Dr. Sizer was discussed at a meeting on September 29, 2014. ${ }^{179}$ The board concludedunanimously-that Dr. Sizer had acted "unwisely and carelessly," but that the Church of England had undertaken "an appropriate disciplinary review," 180 and therefore CEM would take no action against him.

It is important to note the high regard given by CEM to the Church of England's disciplinary procedure, even though the CEM board would likely agree that the Church of England is not an evangelical body. This deference is doubly noteworthy because the above-mentioned document sent to the board had drawn attention to the Church of England's failure to reach a verdict on Dr. Sizer's behavior, leaving the moral questions outstanding. In the view of the authors, the board of CEM would not have deferred to the verdict-free outcome of a disciplinary process overseen by non-evangelicals if one of its Advocates had been accused of anti-Black racism.

In the summer of 2020, CEM was approached by the authors prior to the publication of a post on Medium documenting the Stephen Sizer scandal. ${ }^{181}$ CEM's board was invited to apologize for its 2014 decision to stand by Dr. Sizer. It declined to do so. ${ }^{182}$

Following the death of George Floyd, one CEM board member ${ }^{183}$ wrote, "George Floyd's murder has highlighted racism and prejudice and oppression and violence against black people and we Christians simply must not and cannot sit silently. What will the response of white evangelical leaders in the U.K. be to these critical events?" ${ }^{184}$ Yet CEM has remained resolutely silent about Dr. Sizer's antisemitism and the organization's decision in 2014 not to cut its ties with Dr. Sizer. The board member's comment suggests that CEM would not have maintained that silence if the racism demonstrated by Dr. Sizer had been directed against Black people instead of Jews.

\section{(d) GAFCON}

The Global Anglican Future Conference, or GAFCON, is an international organization representing Anglicans seeking the recovery of biblical Christianity within Anglicanism. ${ }^{185}$

One leader present at the founding of GAFCON was Canon Dr. Chris Sugden. ${ }^{186}$ Dr. Sugden held the significant role of conference director at GAFCON's first major conference, which was held in Jerusalem in 2008. ${ }^{187}$ Dr. Sugden has been a stalwart supporter of Dr. Sizer and currently serves on the board of reference of Dr. Sizer's charity, Peacemaker Trust. ${ }^{188}$

Dr. Sizer attended both the 2008 conference in Jerusalem and also GAFCON's second major conference, held in Kenya, from October 21 to 26, 2013. ${ }^{189} \mathrm{His}$ attendance at the second is particularly significant, because by that date 
numerous Jewish organizations had raised concerns about his activity. Furthermore, the outcome of the CDM discussed above was announced during the conference itself, on October 23. ${ }^{190}$ This means that at the conference's start, it remained possible that he would be officially censured by the Church of England.

There were 1,358 delegates from thirty-eight nations at the Nairobi conference. ${ }^{191}$ Those figures suggest that only limited places were available to each of those nations. Therefore, an invitation to attend could be seen as a mark of the invitee's good standing among the evangelical Anglicans of the sending nation. According to a former GAFCON representative, invitations are tied to local recommendations. ${ }^{192}$

It is unclear how Dr. Sizer came to be invited to attend GAFCON 2013. Nor is it clear how much the then national or global organizers and leaders knew about the controversy surrounding him. What is clear, however, is that a few months later, the late Rev. Prebendary Richard Bewes, one of GAFCON's then directors, ${ }^{193}$ joined the preaching team of Dr. Sizer's church. ${ }^{194}$ One of the authors of this article emailed Rev. Bewes in January 2014 in connection with Dr. Sizer, saying, "When an organization as well-respected as the Board of Deputies makes a stand against an evangelical vicar, we are obliged to look at the facts of the case rather than taking the vicar's word at face value." ${ }^{195}$ Rev. Bewes refused even to discuss the UK Jewish community's criticisms of Dr. Sizer, on the basis that it would be "unproductive." ${ }^{196}$ We can only assume from this response, and from Rev. Bewes's involvement with Dr. Sizer's preaching team, that he would not have opposed Dr. Sizer's attendance at the Kenyan GAFCON conference.

\section{(e) Christ Church Virginia Water (CCVW)}

Dr. Sizer's own congregation at CCVW stood by him throughout his years of notoriety. For several years before his retirement, CCVW allocated annual sums of around $£ 6,000$ to support his international ministry outside the church. ${ }^{197}$ Following his departure in April 2017, CCVW has failed to distance itself from its former vicar's antisemitic statements and activity. In 2018, under the leadership of its new vicar, Rev. Dr. Simon Vibert, ${ }^{198}$ CCVW donated $£ 6,600$ to Dr. Sizer's charity Peacemaker Mediators (now known as Peacemaker Trust; Image 4). ${ }^{199}$

In both March 2019 (Image 5) ${ }^{200}$ and January 2020 (Image 6), ${ }^{201}$ Peacemaker Trust was named "Mission of the Month" in CCVW's Connection magazine.

CCVW evidently maintains the friendliest of relationships with Dr. Sizer, even though, during the final months of his incumbency, he was banned by his bishop from all preaching, teaching, leading of services, and social media activity. It is illuminating to compare CCVW's actions with those of Emmanuel Wimbledon, another conservative evangelical Anglican church. Emmanuel's former vicar, Rev. Jonathan Fletcher, faces various allegations of abuse. ${ }^{202}$ While Emmanuel's response to Fletcher has been criticized, ${ }^{203}$ it has nevertheless distanced itself from its former vicar, stating that when possible it had sought to prevent him ministering elsewhere. ${ }^{204} \mathrm{CCVW}$ has taken the opposite approach with Dr. Sizer.

In June 2020, Rev. Dr. Simon Vibert, Dr. Sizer's successor as CCVW's vicar, tweeted in apparent support of the Black Lives Matter movement (Image 7). ${ }^{205}$ This suggests he takes racial grievances seriously. ${ }^{206}$ However, to the best of our knowledge, he has taken no steps to listen to the Jewish organizations that protested against his predecessor. Of all the Christian organizations that owe Jewish people an apology for failing to act against Dr. Sizer, arguably his own former church comes first. Yet when pressed, Dr. Vibert said, "I have not felt it my duty to try to unpick my predecessor's position on these issues." ${ }^{207}$ In light of his June 2020 tweet, it is hard to avoid concluding that antisemitism does not trouble him to the same extent as racism directed against Black people. 




11 COMMITMENTS UNDER OPERATING LEASES

At 31 December 2018 the company had future minimum lease payments under non-cancellable operating leases as follows:

\begin{tabular}{|c|c|c|}
\hline & 2018 & 2017 \\
\hline Not later than 1 year & $£ 1,056$ & $£ 11,056$ \\
\hline \multirow[t]{2}{*}{ Later than 1 year and not later than 5 years } & $£ 1,848$ & $£ 2,904$ \\
\hline & $£ 2,904$ & $£ 13,960$ \\
\hline
\end{tabular}

\section{TRANSACTIONS INVOLVING RELATED PARTIES}

The expenses paid to clergy may include a small, immaterial proportion which relates to their function as PCC members. All clergy received reimbursement of church-business expenses totalling on an asincurred basis: Rev Stephen Sizer $£ 0$ (2017- $£ 922)$ : Rev Simon Vibert $£ 1,931$ (2017- $£ 734)$, Rev Simon Willetts $£ 1,111$ (2017 - £1,481), Rev Will Bissett $£ 175$ (2017 - £0), Rev Jeremy Brown $£ 454$ (2017 $£ 98$ ). Apart from the above no remuneration or expenses have been paid to any members of the PCC.

A salary, including Employers National Insurance and Pension Contributions, of $£ 13,842$ (2017. $£ 3,886$ ) was paid to Staff Member Caroline Vibert, wife of Vicar Simon Vibert

Payments for administrative services of $£ 3,078$ were made to Sarah Banks, daughter of PCC member Margaret Banks, as well as a salary, including Employers National Insurance and Pension Contributions, of $£ 13,861(2017-£ N / A)$.

PCC Member Colin Rye was an employee of Mission Partner DAI UK up until 31 $1^{\text {st }}$ March 2018. DAI UK received a $£ 6,600$ Outward Giving Fund grant in $2018(£ 7,800$ in 2017).

\section{PCC Member Andrew Pereira is a} $£ 6,600$ Outward Giving Fund grant.

Parishioner and member of the Mission Coordination Team, Ben Niblett is an employee of Mission Partner Tear Fund which received a $£ 6,600$ Outward Giving Fund grant.

The aggregate donations from Related Parties (PCC members and their immediate families) during 2018 was $£ 104,067(2017-£ 81,783)$

IMAGE 4: Extract from CCVW Financial Statements for Year Ended December 31, 2018 (highlighting added).

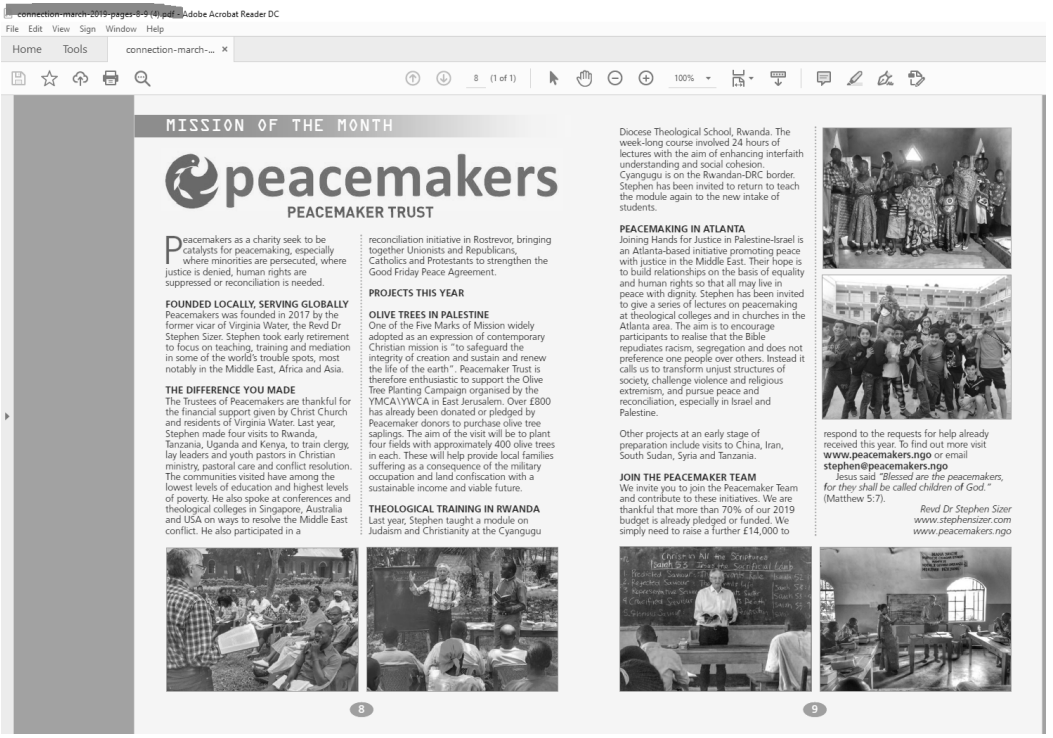

IMAGE 5: Extract from CCVW's Connection magazine, March 2019 (highlighting added). 


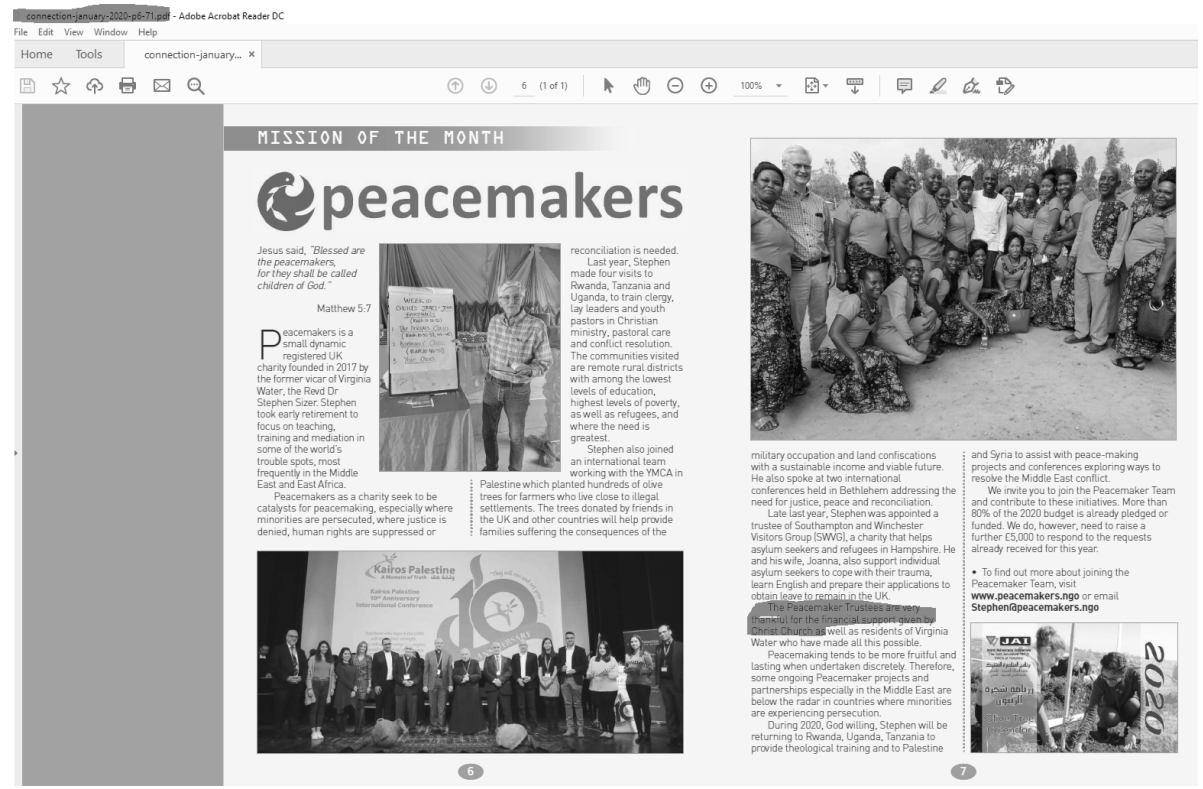

IMAGE 6: Extract from CCVW's Connection magazine, January 2020 (highlighting added).

\section{Simon Vibert}

@Simonvib

What is the matter with that man. IT'S NOT ABOUT

YOU! \#BlackLivesMatter

\section{Team Trump (Text VOTE to 88022) @ @TeamTrump · Jun 5}

"Equal justice under the law must mean that every American receives equal treatment in every encounter with law enforcement regardless of race... Hopefully \#GeorgeFloyd is looking down right now \& saying this is a great thing that's happening for our country...in terms of equality"

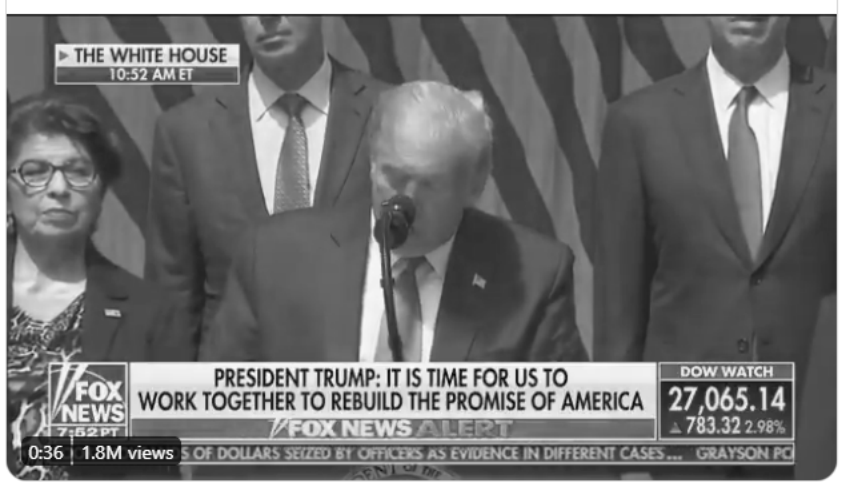

5:37 PM · Jun 5, 2020 from Virginia Water, South East - Twitter for Android

IMAGE 7: Simon Vibert tweet. 


\section{(f) Senior Leaders}

Several senior conservative evangelical leaders were asked by the authors, at various times, to intervene or provide behind-the-scenes assistance. They all declined, apart from Rev. Angus MacLeay, mentioned in Section 7 (b), and the late Rev. Dr. Mike Ovey, then Principal of Oak Hill College. As early as July 2012, commenting on Dr. Sizer's links to antisemitic websites, Dr. Ovey said, "If a member of my Faculty had made these links, I would have had no course, nor inclination, but to dismiss them." He also offered meaningful practical support to one of the authors of this article. ${ }^{208}$

In early 2015, Dr. Ovey alluded to Dr. Sizer at the start of a paper on the role of bishops:

As I write this a senior evangelical church leader has been accused of anti-semitism. Guildford diocese is investigating. One evangelical leader has asked on the web whether UK conservative evangelicalism will put its house in order on this one, a request he has made before with respect to this particular leader over just this issue of anti-semitism. ${ }^{209}$

This influential paper $^{210}$ was circulated among various conservative evangelical leaders under the auspices of ReNew (an organization discussed below). Any readers unaware of the identity of the said "senior evangelical church leader" in "Guildford diocese" could easily have discovered it by an internet search or by asking colleagues.

Dr. Ovey, who died in January 2017, was highly respected within British evangelicalism. His words kept Dr. Sizer's conduct on the radar of those within the conservative evangelical movement who were best-positioned to act against him, had they been so inclined.

Among the leaders to whom the paper was circulated were Rev. William Taylor and Rev. Mark Burkill. ${ }^{211}$ Rev. William Taylor, as seen previously, is Rector of St Helen's Bishopsgate, the erstwhile chair of the SEGP, and Chairman of ReNew. Rev. Mark Burkill was Chairman of
Reform, a major network of Anglican conservative evangelicals, from 2015 until 2018, when Reform merged with Church Society. Rev. Burkill, a long-serving director of the associated Church Society Trust, joined the council of Church Society itself in $2018 .{ }^{212}$ Rev. Taylor, Rev. Burkill, and the other leaders who read Dr. Ovey's words evidently thought that the Sizer scandal warranted no intervention on their part. The authors believe that if Dr. Ovey had highlighted any other form of racism, those readers would not have brushed aside his words.

\section{(g) ReNew}

ReNew, formed in 2013, runs an annual conference. ${ }^{213}$ Its chairman, since its inception, has been Rev. William Taylor. ${ }^{214}$ It is administered from Rev. Taylor's church: St Helen's Bishopsgate, London. ${ }^{215}$ Attendance at the conference is subject to completion of an application form.

In October 2017, Stephen Sizer attended a ReNew conference in Leeds, organized by Anglican Mission in England, Church Society, and Reform. ${ }^{216}$ Contributors included Rev. Taylor himself. This happened after Dr. Sizer's antisemitic conduct had been widely reported; after he had been the subject of two complaints by the Board of Deputies of British Jews; after he had twice broken an agreement with his bishop; and after his books had been withdrawn by IVP. ${ }^{217}$ It also came several years after Rev. Taylor had first been alerted to Dr. Sizer's conduct and asked to exclude Christ Church Virginia Water from the SEGP. By Dr. Sizer's own account, his experience at the conference was convivial-there is no indication that he was challenged or asked to leave, whether by the leaders of the conference or anyone else. ${ }^{218}$ By this point, Rev. Taylor in particular was being nothing if not consistent: he evidently still saw "no justifiable grounds for breaking gospel partnership with Stephen." ${ }^{219}$ It is difficult to avoid concluding that the individual who bears most responsibility for the failure of British conservative evangelicals to take action against Dr. Sizer is Rev. Taylor. 


\section{(h) Church Society}

Church Society exists to promote conservative evangelicalism within the Church of England. ${ }^{220}$ Dr. Sizer himself served as a Church Society trustee between 1996 and 1999. ${ }^{221}$ Since Dr. Sizer's activity was bringing conservative evangelicalism into disrepute, Church Society might have been expected to issue a statement responding to his conduct. ${ }^{222}$ It could have publicly distanced itself from Dr. Sizer, in view of his previous membership of Church Society's governing board. If nothing else, it could have issued a general statement condemning antisemitism without naming Dr. Sizer specifically.

The Director of Church Society, Rev. Dr. Lee Gatiss has said that Dr. Sizer was no longer a member of Church Society by the time his antisemitism was attracting widespread attention. ${ }^{223}$ While that fact may slightly lessen Church Society's culpability, it certainly does not remove it. Church Society's stated mission, according to the home page of its website, is to "reform and renew the Church of England in biblical faith." Dr. Sizer, as a conservative evangelical, was representing biblical faith in the Church of England. By failing to do anything at all about his antisemitism, Church Society was tolerating the presence of antisemitism within the very constituency it seeks to uphold and promote.

One suitable time for Church Society to act was January 2015, when Dr. Sizer's notoriety was at its height. On January 30, 2015, Dr. Sizer's conduct was discussed on Facebook by the Junior Anglican Evangelical Conference (JAEC), a project run by Church Society. Dr. Gatiss, the Director of Church Society, and a moderator of JAEC's Facebook group, participated in that debate, as did Rev. John Telford, then a member of Church Society's Council. ${ }^{224}$ Yet Church Society evidently did not consider the scandal surrounding Dr. Sizer worthy of public comment at that time or any time afterwards until July 2020, when Dr. Gatiss wrote a blog post responding to criticism from the authors of this article. $^{225}$
In that post, Dr. Gatiss claimed he had not previously seen the evidence against Dr. Sizer that the authors had now brought to his attention. (The authors consider this claim to be patently untrue. ${ }^{226}$ Dr. Gatiss also appeared to suggest that the only people aware of Dr. Sizer's conduct were those who followed him on social media, as if his behavior had not been widely reported in the news media, including the Christian news media. ${ }^{227} \mathrm{He}$ described Dr. Sizer's actions as "offensive," "sometimes ridiculous," "indefensible," and "a source of grave concern.” However, he did not explicitly identify Dr. Sizer's conduct as antisemitic. He reported that Church Society's Council was "pleased to see that the Board of Deputies of British Jews had agreed its [2012] complaint about Dr. Sizer's behaviour was resolved (according to the agreed [2013] statement)." But he neglected to mention that the Board had repeated its vehement complaint against Dr. Sizer on the day the 2013 conciliation agreement was announced-an important detail revealing the inadequacy of the disciplinary process. ${ }^{228}$ That detail had been highlighted in the very article to which Dr. Gatiss was responding. ${ }^{229}$ Finally, Dr. Gatissspeaking on behalf of Church Society's Council-expressly refused to apologize for Church Society's earlier failure to criticize Stephen Sizer.

It is possible that Church Society chose not to identify Dr. Sizer's activity as antisemitic in order to avoid applying pressure on Rev. Dr. Simon Vibert, Dr. Sizer's successor at Christ Church Virginia Water. Dr. Vibert is partly responsible for running Church Society's JAEC project, ${ }^{230}$ and he spoke at JAEC's annual conference in 2014, 2017, and $2018 .{ }^{231} \mathrm{He}$ is also one of five contributors to Church Society's 2019 book The Effective Anglican. ${ }^{232}$ If Church Society had identified Dr. Sizer's conduct as antisemitic and apologized for its failure to speak out against him, there would have been awkward knock-on effects for Dr. Vibert. These considerations may have influenced Dr. Gatiss's thinking when he wrote his blogpost. 
Church Society's inaction regarding Dr. Sizer is particularly striking given its willingness to act in a previous case of racism, ${ }^{233}$ and its publicly stated opposition to racism. In June 2020, Church Society addressed racism in a podcast. Both Dr. Gatiss and the Society's Associate Director, Dr. Ros Clarke, stressed the importance of listening to ethnic minorities. ${ }^{234}$ Yet Church Society's statement on Stephen Sizer, issued just weeks later, gives no indication that Church Society had contacted any Jewish organization to put its own advice about listening into practice. ${ }^{235}$ Later in 2020, an edition of Church Society's Crossway magazine focused on racism in detail. The edition featured six articles by authors from ethnic minority backgrounds. However, none were Jewish, and none of the articles considered antisemitism in depth. ${ }^{236}$ This is notable, given the criticism Church Society had received just months beforehand for its specific failure to confront antisemitism. It suggests that Church Society does not treat antisemitism as "real" racism-which would closely fit the thesis of this article.

In February 2021, Church Society produced a podcast titled "Racism, Repentance, Revelation." There was a brief mention of Martin Luther and his antisemitic legacy, but no mention of contemporary antisemitism. ${ }^{237}$ There seems little doubt that Church Society would recognize past antisemitism as being equivalent to other bigotries. What is considerably less certain, however, is whether Church Society considers contemporary antisemitism to be an equal bigotry.

\section{(i) Reform}

According to Rev. Dr. Lee Gatiss, Dr. Sizer belonged to Reform at the time of its 2018 merger with Church Society. ${ }^{238}$ Before the merger, Reform produced statements, articles, and publications on various topical issues relating to the Church of England, ${ }^{239}$ yet it made no statement on Dr. Sizer's antisemitic activity. It had also evidently taken no steps to remove him from membership.

\section{(j) Inter-Varsity Press}

In November 2016, IVP withdrew Dr. Sizer's books from sale-though only after some concerted pressure. The publishing rights were returned to Dr. Sizer himself. ${ }^{240}$ IVP made no public comment about its decision. This is noteworthy, given that it had released a statement when withdrawing the books of a Christian academic on grounds of plagiarism, ${ }^{241}$ and it would do so again in a later case, when withdrawing books by a church leader accused of spiritual abuse. $^{242}$

\section{Assessing the Evangelical Response}

\section{(a) Evangelical Silence}

As indicated above, vanishingly few senior conservative evangelical leaders or organizations either spoke or acted against Dr. Sizer while he was vicar of Christ Church Virginia Water. As of February 2021, Dr. Sizer's antisemitism has never been explicitly condemned by Evangelicals Now, the South East Gospel Partnership, Christianity Explored Ministries, GAFCON, Christ Church Virginia Water, ReNew, or Church Society. Nor has a single senior conservative evangelical leader ever publicly condemned Dr. Sizer's antisemitic conduct.

\section{(b) Two Analogies}

Evangelical silence itself amounts to a form of antisemitism. By way of analogy, a schoolboy who taunts Jewish pupils with antisemitic slurs is obviously guilty of antisemitism, but so too is the school principal who is aware of the taunting and yet refuses to act. In Dr. Sizer's case, the Board of Deputies of British Jews, the Community Security Trust, and the Jewish Leadership Council all spoke out against his activity. So too did the Scottish Council of Jewish Communities, which in 2012 protested against the Church of Scotland's support for a conference at which Dr. Sizer was the keynote 
speaker. ${ }^{243}$ Evangelical organizations and leaders were aware of the substance of those complaints. Their failure to speak out or take timely action demonstrates the same kind of antisemitism as the school principal.

A second analogy reflects recent events. Imagine that a conservative evangelical Anglican vicar writes a critique of the Black Lives Matter (BLM) movement. In itself, that would be defensible: no movement (and still less a specific organization) is beyond criticism. But imagine this minister then becomes increasingly strident. Imagine he links to several explicitly racist websites and, when challenged, gives implausible explanations for doing so. Imagine he attacks the movement at a conference organized by White supremacists. Imagine he-twice-insinuates the movement's complicity in a terrorist atrocity it had nothing to do with. Imagine he captions photographs of Black activists, "BLM members aping the tactics of Marxist guerrilla movements" (racist rhetoric he knows will be inflammatory). Imagine he champions the cause, without any qualification, of a White supremacist infamous for a notorious speech against Black people. Imagine he makes distasteful, irrelevant allusions to a Black celebrity's ethnicity. Imagine if, when challenged, he says that he is not being racist, but "simply criticizing the Black Lives Matter movement." Imagine he accuses his detractors of acting in bad faith, in order to silence him. Imagine his own congregation supports him financially - and continues to do so, even after he leaves parish ministry under a cloud and moves on to other things.

The authors consider it unthinkable that conservative evangelical organizations would fail to act against such a vicar. They would listen carefully to concerns expressed by Black Christians. They would strive to understand why the minister was not simply criticizing the BLM movement, but being racist. They would distance themselves from him, and find ways to act against him—regardless of, and in addition to, any action taken by the Anglican hierarchy.
They would be unimpressed by his defense that "it is not racist to criticize the BLM movement."

The above is, of course, an exact parallel of the Stephen Sizer controversy. Yet the inevitable response of conservative evangelicals to the imaginary case above has been completely lacking in the parallel case in the real world.

\section{(c) A Glaring Discrepancy}

The discrepancy between the response of conservative evangelicals to the antisemitism of Stephen Sizer and their attitude to other forms of racism is glaring and obvious. It is accentuated by the following detail. As mentioned above, in the summer of 2020, when racism was being discussed throughout the world, the authors wrote a Medium post including content similar to this article. ${ }^{244} \mathrm{~A}$ pre-publication draft was emailed to representatives of Evangelicals Now, the SEGP, Christianity Explored Ministries, Church Society, and Christ Church Virginia Water. ${ }^{245}$ They were invited, in a respectful manner, to apologize to the British Jewish community for their failure to speak out or to take timely action against Dr. Sizer. None agreed to do so, and no such apology has been forthcoming since.

\section{(d) The Place of Christian Theology}

This article has argued that the unwillingness of conservative evangelicals to take action against Dr. Sizer exemplifies a wider phenomenon: as numerous observers have pointed out, antisemitism is a bigotry that does not receive the same attention or action as other bigotries. Yet the authors are conscious that some readers will interpret this entire episode differently. There can be no denying the appalling history of Christian antisemitism, and it must be asked whether this saga is better understood simply as a modern instance of that ancient hatred. Could it be that the willingness of British evangelicals to tolerate Dr. Sizer's conduct has been driven by a specifically theological antipathy towards the Jewish people?

The authors themselves hold the view that far from mandating antisemitism, the New Testament displays devoted indebtedness to its 
Jewish heritage. Jesus's statements, "Salvation is from the Jews" (John 4:22), and, "For truly I tell you, until heaven and earth disappear, not the smallest letter, not the least stroke of a pen, will by any means disappear from the Law until everything is accomplished" (Matthew 5:22), should be given their full weight—along with numerous similar statements. There are, of course, other New Testament verses that have been used in the service of antisemitism or antizionism, such as Matthew 27:25, John 8:44, and 1 Thessalonians 2:14-16. We believe these texts reflect what was initially an intra-Jewish struggle. (The writers of all three passages just mentioned were Jews.) When such texts have been used to justify antisemitism or antizionism, they have been illegitimately taken out of that original context. $^{246}$

In our dealings with evangelicals, we have found widespread agreement with this way of understanding the New Testament. ${ }^{247}$ With the possible exception of Dr. Sizer himself, ${ }^{248}$ we have not encountered the theological antisemitism that undoubtedly motivated some Christian leaders in the past. Although we ourselves argue that the failure of British evangelicals to take action against Dr. Sizer is itself a form of antisemitism, ${ }^{249}$ we believe it has much more in common with the antisemitism of large numbers of non-religious British people (namely, an antisemitism that overlooks or is simply apathetic towards Jewish concerns) than with a traditional Christian antisemitism driven by specific theological goals. We therefore think the reaction of British conservative evangelicals to the Sizer scandal can be usefully studied as an example of a broader contemporary phenomenon.

\section{Conclusion: A Lesser Bigotry}

We return to where we started. In August 2020, Hadley Freeman wrote: "Why is there only general agreement about antisemitism when a 41-year-old rapper tweets actual death threats? Antisemitism is, still, seen as a 'lesser bigotry', which is why politicians and newspapers can dabble in it." 250

To Freeman's observations we can, sadly, add our own: antisemitism is still seen by British conservative evangelicals as a lesser bigotry, which is why, for many years, their organizations and senior leaders have consistently failed to speak out or take timely and decisive action against the antisemitic activity of Stephen Sizer.

This article has documented a long-running scandal that supports Freeman's argument. Notwithstanding the protagonists, little about the scandal is distinctively Christian. Stephen Sizer himself represents a familiar strand of contemporary left-wing antisemitism: the antisemitism of "good people," linked to hostility to Israel but very different from legitimate or rational criticism of Israeli policy. ${ }^{251}$ The failure of other British conservative evangelicals to respond to his conduct with the seriousness with which they would respond to other forms of racism similarly reflects a wider phenomenon. It therefore warrants the attention of students of contemporary antisemitism.

One lesson that Jewish community groups may need to learn (or relearn) from this "lesser bigotry thesis" is that simply highlighting incidents of antisemitism may not garner sympathetic action and cooperation from others. It may, for example, be helpful to prepare Jewish freshmen for college campuses where antiracist campaigning is esteemed, yet cases of antisemitism attract little or no attention. One approach may be to use analogies similar to those above. ${ }^{252}$ When antiracists are pressed to explain why they react in one way to racism that targets Black people, and in another way to equivalent antisemitism, they may at least find it difficult to explain the disparity, and then possibly shift their position. Sadly, unless and until antisemitism is viewed as an equal bigotry, such strategies will remain necessary. 


\section{REFERENCES}

1 Hadley Freeman, "After Wiley, I Didn't Have a Fight on My Hands for Once. Why Did That Feel So Weird?" Guardian, August 8, 2020, https://www.theguardian.com/music/commentisfree/2020/aug/08/after-wiley-didnt-have-a-fighton-my-hands-for-once.

2 Zoe Strimpel, "Why Does Cancel Culture Never Apply to Anti-Semitism?" Telegraph, July 19, 2020, https://www. telegraph.co.uk/women/life/does-cancel-culture-never-apply-anti-semitism/.

3 David Baddiel. “David Baddiel: The Racism We Think Doesn't Count," The Times, January 31, 2021, https://www. thetimes.co.uk/article/david-baddiel-the-racism-we-think-doesnt-count-rpcfrgd0g.

4 Jan Shure, "Blyton Is Excoriated, Dahl Is Lionised. Discuss ..." Jewish News, August 22, 2020, https://blogs.timesofisrael.com/blyton-is-excoriated-dahl-is-lionised-discuss/.

5 David Hirsh, Contemporary Left Antisemitism (Abingdon: Routledge, 2017), 168.

6 Howard Jacobson, "Those Who Boycott Israeli Universities Are Doing Intellectual Violence-To Themselves," July 15, 2007, https://spme.org/spme-research/letters-from-our-readers/howard-jacobson-those-who-boycott-israeli-universities-are-doing-intellectual-violence-to-themselves/3521/.

7 "Working Definition of Antisemitism," IHRA, accessed August 27, 2020, https://www.holocaustremembrance.com/ working-definition-antisemitism.

8 Bernard Harrison, "Why Present-day 'Anti-Zionism' is Antisemitic," in Unity and Diversity in Contemporary Antisemitism, ed. Jonathan Campbell and Lesley Klaff (Boston: ASP, 2019), 85.

9 Hirsh, Contemporary Left Antisemitism, 144.

10 Ibid., 265.

11 Ibid., 137-138.

12 See the carefully reasoned argument for those designations in Kwame Anthony Appiah, "The Case for Capitalizing the $B$ in Black," The Atlantic, June 18, 2020, https://www.theatlantic.com/ideas/archive/2020/06/time-to-capitalize-blackand-white/613159/.

13 Justin Taylor, "Stott on the Essence of Evangelicalism," First Things, October 19, 2009, https://www.firstthings.com/ blogs/firstthoughts/2009/10/stott-on-the-essence-of-evangelicalism. A commonly used definition of evangelicalism is the "Bebbington quadrilateral," which identifies four evangelical "distinctives": biblicism; crucicentrism (that is, a focus on the cross); conversionism; and activism. David Bebbington, Evangelicalism in Modern Britain: A History from the 1730s to the 1980s (London: Unwin Hyman, 1989), 2-3. The definition set out above overlaps considerably with the Bebbington quadrilateral but is more closely related to the etymology of the word "evangelical."

14 For example, Emmanuel Wimbledon, a conservative evangelical Anglican church whose former vicar faces allegations of abuse, recently commissioned a report from an independent Christian safeguarding organization rather than simply referring the matter to the hierarchical structures of the Church of England. At the time of writing, the report has yet to be published. Gabriella Swerling, "'Abusive' Vicar Victims Fear Cover-up, as Church Officials Gain Advance Access to Conduct Report," Telegraph, January 22, 2021, https://www.telegraph.co.uk/ news/2021/01/22/abusive-vicar-victims-fear-cover-up-church-officials-gain-advance/.

15 Fellowship of Independent Evangelical Churches, accessed April 4, 2021, https://fiec.org.uk/.

16 Examples include charismatic evangelicalism, which emphasizes particular supernatural manifestations, and open evangelicalism, which questions the traditional evangelical understanding of the sovereignty of God. For an extended discussion of the definition of evangelicalism, see D. A. Carson, The Gagging of God: Christianity Confronts Pluralism (Leicester: Apollos, 1996), 444-461.

17 "About," The Gospel Partnerships, accessed February 3, 2021, https://gospelpartnerships.org.uk/about.

18 AMiE, accessed September 19, 2020, https://www.anglicanmissioninengland.org/.

19 "About," ReNew, accessed September 19, 2020, https://www.renewconference.org.uk/about/.

20 Church Society, accessed September 19, 2020, https://churchsociety.org/.

21 "Reform Archive," Church Society, accessed September 19, 2020, https://churchsociety.org/resources/page/reform_ archive.

22 "Fellowship of Word and Spirit Archive," Church Society, accessed September 19, 2020, https://churchsociety.org/ resources/page/fellowship_of_word_and_spirit_archive. 
23 Ros Clarke, "A United Church Society Annual Meeting," Church Society, May 14, 2018, https://churchsociety.org/blog/ entry/a_united_church_society_annual_meeting.

24 See, for example, "Junior Evangelical Anglican Conference 2013," Church Society, accessed September 27, 2020, https://churchsociety.org/resources/page/junior_anglican_evangelical_conference_2013.

25 "History," GAFCON, accessed September 19, 2020, https://www.gafcon.org/about/history.

26 "About AMiE," AMiE, accessed October 25, 2020, https://www.anglicanmissioninengland.org/about/about-amie/.

27 Christianity Explored, accessed September 19, 2020, https://www.christianityexplored.org/.

28 Evangelicals Now, accessed September 19, 2020, https://www.e-n.org.uk/.

29 "About us," IVP, accessed August 7, 2020, https://ivpbooks.com/about-us.

30 Oak Hill College, accessed August 7, 2020, https://www.oakhill.ac.uk/.

31 St Helen's Bishopsgate, accessed September 19, 2020, https://www.st-helens.org.uk/.

32 "Meet our Team," St Helen's Bishopsgate, accessed September 19, 2020, https://www.st-helens.org.uk/about/meetour-team/.

331 Timothy 3:7.

34 Christ Church Virginia Water, accessed August 5, 2020, https://www.cc-vw.org/.

35 Surrey Gospel Partnership, accessed August 5, 2020, http://surreygospelpartnership.co.uk/churches.

36 The South East Gospel Partnership, accessed August 5, 2020, https://segp.org.uk/.

37 "Stephen Robert Sizer," Companies House, search performed August 5, 2020, https://beta.companieshouse.gov.uk/ officers/5UBeFvM7qTitAn2eUn7OKLijY9M/appointments.

38 Lee Gatiss, "Response to a blogpost about Stephen Sizer," Church Society, July 28, 2020, https://churchsociety.org/ blog/entry/response_to_a_blogpost_about_stephen_sizer.

39 Author search: Stephen Sizer, Evangelicals Now, search performed August 5, 2020, https://www.e-n.org.uk/ search?f=source\&q=stephen+sizer.

40 "Our Purpose," Biblica, accessed August 5, 2020, https://www.biblicaeurope.com/about/our-purpose; "Stephen Robert Sizer," Companies House.

41 "About," Stephen Sizer (website), accessed August 7, 2020, http://stephensizer.com/about/.

42 Stephen Sizer, Christian Zionism: Roadmap to Armageddon? (Nottingham: Inter-Varsity Press, 2004), 10-13.

43 Stephen R Sizer, "The Promised Land: A Critical Investigation of Evangelical Christian Zionism in Britain and the United States of America since 1800" (PhD diss., Middlesex University and Oak Hill College, 2002), accessed August 7, 2020, http://eprints.mdx.ac.uk/6403/.

44 "Articles," Stephen Sizer (website), accessed August 7, 2020, http://stephensizer.com/articles-list/;"Media," Stephen Sizer (website), accessed August 7, 2020, http://stephensizer.com/podcast/.

45 Stephen Sizer, Zion's Christian Soldiers? (Nottingham: Inter-Varsity Press, 2007), 15.

46 Stephen Sizer, email to author 2, December 8, 2008.

47 Sizer, Christian Zionism, 205.

48 Ibid., 208.

49 Paul Johnson, A History of the Jews (London: Phoenix Press, 2001), 578-579.

50 Sizer, Christian Zionism, 208.

51 Hirsh, Contemporary Left Antisemitism, 135.

52 Ronald Eissens, "WCAR, the morning after-October 2001," ICARE, accessed August 16, 2020, http://www.icare. to/wcar/.

53 Sizer, Christian Zionism, 209.

54 Ibid., 209; quoting from United Nations, "World Conference against Racism, Racial Discrimination, Xenophobia and Related Intolerance Declaration," adopted on September 8, 2001, section 65.

55 Efraim Karsh, "The Palestinians and the 'Right of Return,"'Commentary, May 2001, section 1, https://www.commentarymagazine.com/articles/efraim-karsh/the-palestinians-and-the-right-of-return/; see also Martin Gilbert, The Routledge Atlas of the Arab-Israeli Conflict, 7th ed. (London: Routledge, 2002), 54.

56 Dr. Sizer clarifies elsewhere that he sees both those originally displaced in 1948, and their descendants, as "refugees." He numbers Palestinian refugees at over 3.5 million. Sizer, Christian Zionism, 244. 
57 Chris McGreal, "White House Reporter Helen Thomas Resigns after Anti-Israel Comments," Guardian, June 8, 2010, https://www.theguardian.com/world/2010/jun/07/white-house-reporter-helen-thomas-resigns.

58 Stephen Sizer, "Helen Thomas: You Cannot Criticize Israel in the US and Survive," Stephen Sizer (blog), October 14, 2010, https://stephensizer.blogspot.com/2010/10/helen-thomas-you-cannot-criticize.html.

59 Sizer, Zion's Christian Soldiers, 15.

60 Sizer, "The Promised Land," 310.

61 Sizer, Christian Zionism, 261.

62 Sizer, Zion's Christian Soldiers? 15.

63 Hirsh, Contemporary Left Antisemitism, 265.

64 Ibid., 138.

65 "101 Books Every White Man Must Read," Colchester Collection, accessed October 4, 2020, http://www.colchestercollection.com/must-read.html.

66 The Revisionist Clarion, Aaargh, accessed October 4, 2020, http://aaargh.vho.org/engl/actual/recla.html.

67 Stephen Sizer, "Where to find Christ in the Promised Land," Evangelicals Now, accessed August 16, 2020, https:// www.e-n.org.uk/1996/10/features/where-to-find-christ-in-the-promised-land/.

68 See, for example, Jovan Byford, "Conspiracy Theories," in Key Concepts in the Study of Antisemitism, ed. Sol Goldberg, Scott Ury, and Kalman Weiser (Cham, Switzerland: Palgrave Macmillan, 2021), 79-92, https://doi.org/10.1007/9783-030-51658-1_7.

69 Sizer, Christian Zionism, $251 \mathrm{fn} 170$.

70 Ibid., 243.

71 BBC News, "Ken Livingstone: Jeremy Corbyn Announces New Investigation," April 5, 2017, https://www.bbc.co.uk/ news/uk-politics-39499640.

72 James Mendelsohn, "Stephen Sizer and Dale Crowley," Large Blue Footballs, October 13, 2016, https://largebluefootballs.wordpress.com/2016/10/13/stephen-sizer-and-dale-crowley/.

73 Sizer, Christian Zionism, 21-22.

74 Sizer, "The Promised Land," 8, 10.

75 Stephen Sizer, "Church's Share Sale is not Anti-Semitic," Independent, February 20, 2006, https://www.independent. co.uk/voices/letters/letters-black-musicians-and-the-media-5337155.html.

76 Stephen Bates, "Sacks Accuses Synod of Bulldozer Ill-Judgment," Guardian, February 16, 2006, https://www. theguardian.com/media/2006/feb/17/pressandpublishing.religion.

77 David Hirsh, Anti-Zionism and Antisemitism: Cosmopolitan Reflections (New Haven, CT: Yale Initiative for the Interdisciplinary Study of Antisemitism, 2007), 91-92.

78 Hirsh, Contemporary Left Antisemitism, 32.

79 Image 1: Stephen Sizer, Photographs, "Palestine 2006-Arbeit Macht Frei," accessed November 12, 2008, htttp.www. sizers.org/photos/bethlehem/album/index.html. This link no longer works.

80 Lesley Klaff, "Holocaust Inversion and Contemporary Antisemitism," Fathom (Winter 2014), accessed August 18, 2020, https://fathomjournal.org/holocaust-inversion-and-contemporary-antisemitism/.

81 Alan Hart, Hart of the Matter \#5: Reverend Dr. Stephen Robert Sizer, November 6, 2008, accessed July 20, 2020, http://www.alanhart.net/hart-of-the-matter-5-reverend-dr-stephen-robert-sizer/. The extract in question is at 17:40-18:00.

82 Stephen Sizer, "Payback for Monica? Clinton Rebukes Israel Twice in Two Weeks," Stephen Sizer (blog), March 12, 2010, https://stephensizer.blogspot.com/2010/03/payback-for-monica-clinton-rebukes.html.

83 Image 2: Stephen R Sizer, "Herod's Soldier's [sic] operating in Bethlehem today," Flickr, March 14, 2010, http://www. flickr.com/photos/stephensizer/sets/72157623675922174. Stephen Sizer has since changed the title.

84 See Section 3 (a).

85 Stephen Sizer, "Helen Thomas," emphases added.

86 Joseph W, "Church of England Vicar's Theory about Mass Murder \& Jewish Blood," Harry's Place, March 9, 2011, http:// hurryupharry.net/2011/03/09/church-of-england-vicars-theory-about-mass-murder-jewish-blood/.

87 "Habibi," Stephen Sizer — the Zionists and the EDL Are a Team!, YouTube video, June 13, 2011, https://www.youtube. com/watch?v=hPW1s5cNRpg\&feature=emb_title. 
88 David Graham \& Jonathan Boyd, Committed, Concerned and Conciliatory: The Attitudes of Jews in Britain towards Israel, Institute for Jewish Policy Research, July 2010, 9, 12, 16 (available at https://www.jpr.org.uk/ publication?id=94).

89 "Nailing the EDL-Zionist Lie," CST, October 17, 2013, https://cst.org.uk/news/blog/2013/10/17/nailing-the-edl-zionist-lie.

90 "Habibi," Stephen Sizer-Zionists Have Bought America!, YouTube video, June 13, 2011, https://www.youtube. $\mathrm{com} /$ watch?time_continue $=42 \& \mathrm{v}=4 \mathrm{ME} 6 \mathrm{GueA}-4 \mathrm{~s} \&$ feature $=\mathrm{emb}$ _logo.

91 Stephen Sizer, Syafig Talks about Viva Palestina Malaysia, Vimeo, June 12, 2011, accessed January 31, 2021, https:// vimeo.com/24993637, 0:55-1:40; note particularly Rev. Sizer's interjections at 1:30 ("profits") and 1:38 ("Yah").

92 David Lewis, "Border Systems Error 'Let Sheikh Raed Salah Enter UK,"' BBC News, July 12, 2011, https://www.bbc. co.uk/news/uk-14048648.

93 Ibid.

94 Marcus Dysch, "Blood Libel Cleric Salah Told: You're Welcome to Stay," Jewish Chronicle, April 11, 2012, https://www. thejc.com/news/uk/blood-libel-cleric-salah-told-you-re-welcome-to-stay-1.32796.

95 Stephen Sizer, "Sheik Raed Salah: Britain's First Palestinian Political Prisoner," Stephen Sizer (blog), July 28, 2011, https://stephensizer.blogspot.com/2011/07/sheik-raed-salah-britains-first.html.

96 "Stephen Sizer and the Palestine Telegraph," Harry's Place, July 5, 2011, http://hurryupharry.net/2011/07/05/ stephen-sizer-and-the-palestine-telegraph/.

97 "Stephen Sizer's Reading Habits," Harry's Place, October 13, 2011, http://hurryupharry.net/2011/10/13/stephensizer\%E2\%80\%99s-reading-habits/.

98 "Stephen Sizer Posts Another Racist Link," Harry's Place, March 15, 2012, http://hurryupharry.net/2012/03/15/ stephen-sizer-posts-another-racist-link/.

99 See, for example, the analysis in: "Please Try This Little Experiment," Harry's Place, June 22, 2012, http://hurryupharry. net/2012/06/22/please-try-this-little-experiment/; and Bernard Nicholas Howard, "Stephen Sizer:The Unanswered Questions," Harry's Place, May 2, 2012, http://hurryupharry.net/2012/05/02/stephen-sizer-the-unanswered-questions/.

100 Stephen Sizer, "Extradition: Friday 6th July," July 6, 2012, Stephen Sizer (blog), https://stephensizer.blogspot. com/2012/06/extradition.html;"Rev. Sizer Organising Defence for Pro-Jihadist Suspects in Anglican Church," Harry's Place, June 26, 2012, http://hurryupharry.net/2012/06/26/rev-sizer-organising-defence-for-pro-jihadist-suspects-in-anglican-church/.

101 Richard Millett, "This Could Be the Last Quds Day Demo," Jewish Chronicle, August 25, 2011, https://www.thejc. com/news/uk/this-could-be-last-quds-day-demo-1.26849.

102 Craig Murray, "Collateral Damage: Vince Fean the Wrong Target," March 5, 2013, https://www.craigmurray.org.uk/ archives/2013/03/collateral-damage-vince-fean-the-wrong-target/.

103 Daphne Anson, "'Professional East Europian [sic] Murderers': Salim Says, Sizer Says," Daphne Anson (blog), March 7, 2013, https://daphneanson.blogspot.com/2013/03/professional-east-europian-sic.html.

104 "Rev. Stephen Sizer Speaking at Antisemitic Conference in Iran," CST, October 2, 2014, https://cst.org.uk/news/ blog/2014/10/02/rev-stephen-sizer-speaking-at-antisemitic-conference-in-iran.

105 Lizzie Dearden, "Vicar Investigated over Facebook Post Linking to 'Anti-Semitic'Article ' $9 / 11$ Israel Did It," Independent, January 30, 2015, https://www.independent.co.uk/news/uk/home-news/vicar-investigated-over-facebook-post-linking-to-anti-semitic-article-911-israel-did-it-10012794.html.

106 See Section 5, particularly the final three paragraphs.

107 We return to the role of Christian theology in Section 8 (d) below.

108 Hirsh, Contemporary Left Antisemitism, 1.

109 Ibid.

110 lbid.

111 Miriam Shaviv, "UK Jews Complain to Church of England over 'Anti-Semitic'Vicar," The Times of Israel, October 31, 2012, https://www.timesofisrael.com/uk-jews-complain-to-church-of-england-over-anti-semitic-vicar/.

112 Marcus Dysch, "'Antisemite' Vicar in Board of Deputies Complaint," Jewish Chronicle, November 1, 2012, https:// www.thejc.com/news/uk/antisemite-vicar-in-board-of-deputies-complaint-1.37766. 
113 "Conciliation Report to the Bishop of Guildford Following a Complaint by the Board of Deputies of British Jews under the Clergy Discipline Measure Concerning the Revd Dr. Stephen Sizer," October 14, 2013, http://www. stephensizer.com/wp-content/uploads/2013/10/ConcilFINALAGREEMENT.pdf.

114 Ruth Gledhill, "Vicar Agrees to Take More Care after Anti-Semitism Row," The Times, October 23, 2013, https://www. thetimes.co.uk/article/vicar-agrees-to-take-more-care-after-anti-semitism-row-qpntw229p7k.

115 Gavin Hyman, “Don Cupitt," in The Palgrave Handbook of Radical Theology, ed. Christopher D. Rodkey and Jordan E. Miller (Cham, Switzerland: Palgrave Macmillan, 2018), 138.

116 Dearden, "Vicar Investigated."

117 BBC, "Vicar's 9/11 Facebook Post Investigated by Church," January 30, 2015, https://www.bbc.co.uk/news/ uk-31052648.

118 Justin Cohen, "'Show Me Evidence Israel Wasn't Behind 9/11', Asks Vicar Stephen Sizer," Jewish News, January 29, 2015, https://jewishnews.timesofisrael.com/show-evidence-israel-wasnt-behind-911-asks-vicar-stephen-sizer/.

119 In October 2018, Bishop Watson coauthored a letter criticizing GAFCON for requiring conference participants to sign a set of evangelical doctrines known as the "Jerusalem Statement." "Remaining Faithful within the Church of England," accessed January 26, 2021, http://www.ceec.info/uploads/4/4/2/7/44274161/letter_to_gafcon_oct_2018. pdf. In doing so, Bishop Watson both distanced himself from GAFCON, a conservative evangelical organization, and also rejected a normative conservative evangelical practice: seeking to guard the faith through statements addressing current doctrinal challenges.

120 Diocese of Guildford, "Statement on the Revd Stephen Sizer by the Bishop of Guildford," February 9, 2015, https:// web.archive.org/web/20190717080859/https://www.cofeguildford.org.uk/whats-on/news/detail/2015/02/09/ statement-on-the-revd-stephen-sizer-by-the-bishop-of-guildford. A video of the Bishop's statement is also available: Diocese of Guildford, Statement on Stephen Sizer-The Bishop of Guildford, YouTube video, February 9 , 2015, https://www.youtube.com/watch?v=oiyBVexNcT0.

121 Diocese of Guildford, "Statement."

122 Ibid.; Stephen Sizer's written undertaking, dated February 4, 2015, is available at https://web.archive.org/ web/20190717080859/http://www.cofeguildford.org.uk/docs/default-source/news-documents/stephen-sizerletter.pdf?sfvrsn=2.

123 Diocese of Guildford, "Statement."

124 Marcus Dysch, "Stephen Sizer Warned after Attending Anti-Israel Meeting," Jewish Chronicle, November 2, 2016, https://www.thejc.com/news/uk/stephen-sizer-warned-after-attending-anti-israel-meeting-1.54499.

125 Daphne Anson, “Forgotten Something, Vicar?" Daphne Anson (blog), March 1, 2017, https://daphneanson. blogspot.com/2017/03/forgotten-something-vicar.html? showComment=14884543057 19\#c1561199416871485576.

126 Raphael Ahren, "Israel Slams Sweden for Invoking Palestinian Plight while Discussing Paris Attacks," The Times of Israel, November 16, 2015, https://www.timesofisrael.com/israel-slams-sweden-for-invoking-palestinian-plight-in-paris-attacks/.

127 Daniel Sugarman, "Board of Deputies 'Disappointed' as Church Allows Controversial Vicar Last Hurrah," Jewish Chronicle, March 10, 2017, https://www.thejc.com/news/uk/board-of-deputies-disappointed-as-church-allowsstephen-sizer-last-hurrah-1.434119.

128 Peacemakers, accessed August 21, 2020, https://peacemakers.ngo/.

129 The Red Roar (@theredroar), Twitter, June 5, 2018, https://twitter.com/TheRedRoar/status/1004066000055218178 (particularly 0:50-1:00); Adam Holland (@ad_holland), Twitter, September 11, 2018, https://twitter.com/ad_ holland/status/1039542174503841792.

130 David Hirsh, "Steven [sic] Sizer Pushes Antisemitic Conspiracy Theory, Jeremy Corbyn Defends Him as a Victim of the Lobby," Engage, August 26, 2018, https://engageonline.wordpress.com/2018/08/26/steven-sizer-pushes-antisemitic-conspiracy-theory-jeremy-corbyn-defends-him-as-a-victim-of-the-lobby-david-hirsh/.

131 A screenshot of Dr. Sizer's Facebook post is available via Lee Harpin (@Imharpin), Twitter, February 2021, https:// twitter.com/Imharpin/status/1366016479850823681.

132 "Two Scottish Palestine Activists Convicted over Israeli Store Protest," Jewish News, July 18, 2017, https://jewishnews.timesofisrael.com/two-scottish-palestine-activists-convicted-over-israeli-store-protest/. 
133 "Vicar's 9/11 Facebook Post Investigated by Church," BBC, January 30, 2015, https://www.bbc.co.uk/news/ uk-31052648.

134 "Search Results: Stephen Sizer," Harry's Place, search performed January 2, 2021, http://hurryupharry.net/?s=stephen+sizer.

135 Melanie Phillips, "Beware the New Axis of Evangelicals and Islamists," Spectator, March 7, 2009, https://www. spectator.co.uk/article/beware-the-new-axis-of-evangelicals-and-islamists.

136 Bernard Nicholas Howard, "The Asymmetry of Racism Awareness," Standpoint, February 9, 2012, https://standpointmag.co.uk/features-january-february-12-web-only-the-asymmetry-of-racism-awareness-rev-nick-howardstephen-sizer-anti-semitism/.

137 Adam Wagner, "The Context of the Latest Jeremy Corbyn Anti-Semitism Row Makes It Worse, not Better," New Statesman, August 24, 2018, https://www.newstatesman.com/politics/uk/2018/08/context-jeremy-corbyn-anti-semitism-john-mcdonnell-today-show-labour.

138 Search results for "Stephen Sizer," The Times, search performed August 21, 2020, https://www.thetimes.co.uk/ search?source=search-page\&q=\%22stephen+sizer\%22; "Corbyn and Antisemitism," The Times, March 26, 2018, https://www.thetimes.co.uk/article/corbyn-and-antisemitism-w5hmx3gnb.

139 John Bingham, "Church Bans 9/11 Israel Conspiracy Priest from Using Social Media," Telegraph, February 9, 2015, https://www.telegraph.co.uk/news/religion/11399986/Vicar-who-blamed-Israel-for-911-attacks-is-banned-fromwriting-about-the-Middle-East.html.

140 Chris Richards, "Vicar Probed after Posting Article on Facebook'Blaming ISRAEL for 9/11,"' Mirror, January 30, 2015, https://www.mirror.co.uk/news/uk-news/rev-stephen-sizer-vicar-probed-5069098.

141 Steve Doughty, "Priest Banned from Using Social Media Sites for Six Months after Posting 'Anti-Semitic' Comments Claiming Israel Was behind 9/11," Daily Mail, February 10, 2015, https://www.dailymail.co.uk/news/article-2946831/ Priest-banned-using-social-media-sites-six-months-posting-anti-Semitic-comments-claiming-Israel-9-11.html.

142 Dearden, "Vicar Investigated."

143 Press Association, "Vicar Faces Social Media Ban over Facebook Post Linking 9/11 to Israel," Guardian, February 9, 2015, https://www.theguardian.com/world/2015/feb/09/vicar-faces-social-media-ban-over-facebook-post-linking911-to-israel.

144 Yair Rosenberg, "Why Just 13 Percent of British Jews Say They Will Vote for Labour in the General Election," Tablet, May 30, 2017, https://www.tabletmag.com/sections/news/articles/why-just-13-percent-of-british-jews-say-theywill-vote-for-labour-in-the-general-election.

145 The JC Leader, "To All Our Fellow British Citizens," Jewish Chronicle, November 7, 2019, https://www.thejc.com/ comment/leaders/to-all-our-fellow-british-citizens-1.491812.

146 Hirsh, "Contemporary Left Antisemitism," 6, 32, 43-46.

147 Search results for "Stephen Sizer," Jewish Chronicle, search performed February 7, 2021, https://www.thejc.com/ search?q=stephen+sizer\&searchType=exact\&yearFrom $=2012 \&$ yearTo=2020\&sortBy=latest\&search=true.

148 Search results for "Stephen Sizer," Jewish News, search performed August 21, 2020, https://jewishnews.timesofisrael.com/search/?q=stephen+sizer\&submit=search.

149 Search results for "Sizer," Church Times, search performed August 21, 2020, https://www.churchtimes.co.uk/ search-results?query=sizer.

150 Search results for "Stephen Sizer," Church of England Newspaper, search performed August 21, 2020, https://www. churchnewspaper.com/?s=stephen+sizer.

151 Search results for "Stephen Sizer," Archbishop Cranmer, search performed August 21, 2020, https://archbishopcranmer.com/?s=stephen+sizer.

152 There are, for example, uncompromising criticisms of the Anglican hierarchy in "Episcopacy and Evangelical Leadership," an address given by Church Society Director Rev. Dr. Lee Gatiss on May 14, 2020, https://soundcloud.com/ churchsociety/episcopacy-and-evangelical-leadership.

153 That letter remains available at https://wwedletter.wordpress.com/2011/09/27/w-w-e-d-what-will-evangelicals-do/.

154 Author 2, email to John Benton (then Managing Editor of Evangelicals Now), September 27, 2011.

155 William Mackenzie (then Chairman of Directors of Evangelicals Now), email to author 2, October 4, 2011. 
156 "Sizer Warned," Evangelicals Now, April 2015, https://www.e-n.org.uk/2015/04/uk-news/sizer-warned/.

157 "News in Brief: Closed Book," Evangelicals Now, January 2017, https://www.e-n.org.uk/2017/01/uk-news/newsin-brief/.

158 In September and November 2019, EN published letters making claims and counter-claims regarding the abuse perpetrated by Rev. Jonathan Fletcher-precisely the kind of exchange EN refused to publish in the case of Dr. Sizer.

159 As of January 26, 2021, typing "Stephen Sizer" into the search function of the Jewish Chronicle brings up fifty-one hits for the period between 2012 and 2020, https://www.thejc.com/search?q=stephen+sizer\&searchType=exact\&yearFrom $=2012 \&$ yearTo=2020\&sortBy=latest\&search=true.

160 The South East Gospel Partnership, accessed August 22, 2020, https://segp.org.uk/.

161 Gospel Partnerships, accessed August 22, 2020, https://gospelpartnerships.org.uk/.

162 William Taylor, email to author 2, March 6, 2012.

163 William Taylor, email to author 2, March 22, 2012.

164 William Taylor, email to author 2, July 4, 2012.

165 Angus MacLeay, email to author 2, November 28, 2016.

166 Ibid.

167 "Leading London Evangelical Parish Announces 'Broken Partnership' with the Church of England's House of Bishops," Anglican Ink, December 18, 2020, https://anglican.ink/2020/12/18/leading-london-evangelical-parish-announces-broken-partnership-with-the-church-of-englands-house-of-bishops/.

168 Richard Coekin, "George Floyd: A White Christian's Response," Co-Mission, June 2, 2020, https://co-mission.org/ article/featured/george-floyd/.

169 John Stevens, "Biblical Foundations for Parachurch Organisations: Gospel Partnership and Gospel Unity in the UK," Dissenting Opinion, June 8, 2014, http://www.john-stevens.com/2014/06/biblical-foundations-for-parachurch.html.

170 John Stevens, "Racism: The Gospel Demands We Confront the Evil of Racism So Tragically Highlighted by the Death of George Floyd," Dissenting Opinion, June 4, 2020, http://www.john-stevens.com/2020/06/racism-gospel-demands-we-confront-evil.html.

171 Image 3: St Helen's Bishopsgate (@sthelenschurch), Twitter, June 24, 2020, https://twitter.com/sthelenschurch/ status/1275693728951345153.

172 See subpoint (e), below.

173 John Stevens (@_JohnStevens), Twitter, June 4, 2020, https://twitter.com/_JohnStevens/ status/1268550173581627399.

174 See Section 4.

175 See subpoint (e), below.

176 See, for example, John Stevens, "Same-Sex Relationships: Sorry Bishop, But the Meaning of Holiness Does not Change from Generation to Generation," Dissenting Opinion, February 7, 2019, http://www.john-stevens. com/2019/02/same-sex-relationships-sorry-bishop-but.html.

177 Bernard Nicholas Howard, "Stephen Sizer: The Unanswered Questions," Harry's Place, May 2, 2012, http://hurryupharry.net/2012/05/02/stephen-sizer-the-unanswered-questions/.

178 Bernard Nicholas Howard, "Stephen Sizer-An Assessment," accessible via https://largebluefootballs.files.wordpress. com/2020/06/stephen-sizer-september-2014-c-ex-v3.pdf.

179 Email from Christianity Explored board member to author 2, September 30, 2014.

180 Ibid.

181 Bernard Nicholas Howard and James Mendelsohn, "The Racism Within," Nick Howard, July 27, 2020, https:// nickhoward76.medium.com/the-racism-within-42c9ba10369.

182 Email correspondence between CEM board member and author 1, July 2020.

183 "Jeremy Samuel John Marshall," Companies House, search performed January 10, 2021, https://find-and-update. company-information.service.gov.uk/officers/LqeB77_GtEP6lalzm8WiRffeaa8/appointments.

184 Jeremy Marshall, "Book Review: 'We Need to Talk about Race,"' God, Gold, and Generals, June 2, 2020, https:// jsjmarshall.blogspot.com/2020/06/book-review-we-need-to-talk-about-race.html.

185 "About," GAFCON, accessed September 29, 2020, https://www.gafcon.org/about. 
186 See his account of the origins of GAFCON in Chris Sugden, "South Africa-The Need for GAFCON," Virtue Online, September 3, 2009, https://virtueonline.org/south-africa-need-gafcon-chris-sugden.

187 "Staff," Oxford Centre for Religion and Public Life, accessed April 27, 2021, https://www.ocrpl.org/about/staff/.

188 "People," Peacemakers, accessed April 27, 2021, https://peacemakers.ngo/people/.

189 "Nairobi 2013," GAFCON, accessed September 29, 2020, https://www.gafcon.org/events/nairobi-2013. Dr. Sizer's presence at the two conferences is attested by the photographs he took in 2008: https://www.flickr.com/photos/ stephensizer/sets/72157606091667469/; and in 2013: https://www.flickr.com/photos/stephensizer/ albums/72157638360708876/page1.

190 "A Statement from the Diocese of Guildford," Stephen Sizer (website), accessed September 29, 2020, http://www. stephensizer.com/wp-content/uploads/2013/10/Stephen-Sizer-Board-of-Deputies-Conciliation-October-2013.pdf.

191 "Nairobi Communique and Commitment," GAFCON, accessed October 14, 2020, https://www.gafcon.org/news/ nairobi-communique-and-commitment.

192 Facebook communication, September 8, 2020.

193 "Richard Thomas Bewes," Companies House, search performed October 14, 2020, https://find-and-update.company-information.service.gov.uk/officers/UwscH4EdSBS0B4xkmo8ygRM1tKU/appointments.

194 Stephen Sizer, "Richard Bewes Joins Christ Church Team," December 31, 2013, Stephen Sizer (website), https:// stephensizer.com/2013/12/richard-bewes-joins-christ-church-preaching-team/.

195 Author 2, email to Richard Bewes, January 21, 2014.

196 Richard Bewes, email to author 2, January 24, 2014.

197 James Mendelsohn, "Christ Church Virginia Water's Support for Stephen Sizer," Large Blue Footballs, July 24, 2020, https://largebluefootballs.wordpress.com/2020/07/24/christ-church-virginia-waters-ongoing-support-for-stephen-sizer/.

198 "Simon Vibert," Christ Church Virginia Water, accessed August 27, 2020, https://www.cc-vw.org/index.php?zonename=simonvibert333.

199 Image 4: Christ Church Virginia Water, "Report and Accounts for the Year to 31 December 2018," 24; the accounts are publicly available via the Charity Commission website and can also be downloaded via "Christ Church Virginia Water's support for Stephen Sizer," Large Blue Footballs, July 24, 2020, https://largebluefootballs.wordpress. com/2020/07/24/christ-church-virginia-waters-ongoing-support-for-stephen-sizer/.

200 Image 5: Christ Church Virginia Water, Connection (March 2019): 8-9, https://peacemakers.ngo/2019/03/25/ mission-of-the-month/and https://peacemakermediators.files.wordpress.com/2019/03/connection-march-2019pages-8-9.pdf.

201 Image 6: Christ Church Virginia Water, Connection (January 2020): 6-7, https://peacemakers.ngo/2019/12/30/ mission-of-the-month-at-christ-church-virginia-water/?fbclid=IwAR2fMJfCOnn9tIJLtsx4pwgV51VHOvWmnzDE6LG4X4qOkTFuGmvCmwEsbRA and https://peacemakermediators.files.wordpress.com/2019/12/connection-january-2020-p6-71.pdf.

202 "Church of England Vicar, 77, Could Face Criminal Probe after Alleged Abuse Victims Claim They Endured Naked Ice Baths, Beatings and Massages," Daily Mail, December 27, 2019, https://www.dailymail.co.uk/news/article7829163/Church-England-reverend-Jonathan-Fletcher-77-Wimbledon-south-London-fresh-abuse-claims.html.

203 Speak Life, When Christians Are Compromised - LIVEcast, YouTube video, July 2, 2019, https://www.youtube. com/watch?v=u9Ty2h4HtCg, particularly 45:15-48:15.

204 Sarah Hall, "Response to the Telegraph Article, 22/6/19," Emmanuel Wimbledon, June 22, 2019, https://www. emmanuelwimbledon.org.uk/Groups/325392/Emmanuel_Wimbledon/About_Us/Safeguarding/Safeguarding_ Statement_21/Safeguarding_Statement_21.aspx.

205 Image 7: Simon Vibert (@Simonvib), Twitter, June 5, 2020, https://twitter.com/Simonvib/ status/1268945034457616386.

206 Whether he supports the specific Black Lives Matter organization is of course another matter.

207 Email to author 2, June 22, 2020.

208 Mike Ovey, email to author 2, July 25, 2012.

209 Mike Ovey, "'We Want Our Own Bishops': The Challenges of Oversight," ReNew discussion paper for AMiE Bishops Panel, 2015. The spelling "anti-semitism" is in Dr. Ovey's original. Dr. Ovey mentions an evangelical leader raising 
concerns about Dr. Sizer. The authors assume he means author 2.

210 It is the "widely circulated" paper mentioned in Peter Sanlon, "Silent Anglicans: Why Evangelicals in the Church of England Need to Talk Openly," August 27, 2018, https://fcasa.wordpress.com/2018/08/28/silent-anglicans-whyevangelicals-in-the-church-of-england-need-to-talk-openly/.

211 Rev. Dr. Peter Sanlon, email to author 1, September 26, 2020.

212 "Mark Edward Burkill" Companies House, search performed September 8, 2020, https://beta.companieshouse.gov. uk/officers/g_s6UUZQ_rdrJRutfZz-7AbfV3M/appointments; "Church Society Council," Church Society, accessed September 8, 2020, https://churchsociety.org/society/page/our_council_and_staff/; “A United Church Society Annual Meeting," Church Society, May 14, 2018, https://churchsociety.org/blog/entry/a_united_church_society_ annual_meeting.

213 "About," ReNew, accessed September 27, 2020, https://www.renewconference.org.uk/about/.

214 Rev. Dr. Peter Sanlon, email to author 1, September 27, 2020; "About," ReNew.

215 "Support," ReNew, accessed September 27, 2020, https://www.renewconference.org.uk/support/.

216 Church Society, Podcast, "Episode 3: ReNew 2017," accessed October 11, 2020, https://soundcloud.com/churchsociety/episode-3-renew-2017, 1:05-1:15.

217 See Section 7 (j), below.

218 Stephen Sizer, "Renewing the Church of England," Stephen Sizer (website), October 1, 2017, https://www.stephensizer.com/2017/10/renewing-the-church-of-england/.

219 See Section 7 (b), above.

220 The home page of its website states, "We are a fellowship contending to reform and renew the Church of England in biblical faith." This is a label-free way of speaking about conservative evangelicalism. Church Society website, accessed January 11, 2021, https://churchsociety.org/.

221 "Stephen Robert Sizer," Companies House, search performed August 5, 2020, https://beta.companieshouse.gov. uk/officers/5UBeFvM7qTitAn2eUn7OKLijY9M/appointments. After 1999, Dr. Sizer appears to have left the Society for a period of time, before briefly becoming a member again as a result of its merger with Reform in 2018. Gatiss, "Response."

222 Church Society has published statements responding to other scandals involving conservative evangelicals. See "Serving the Truth in Scandal," Church Society, February 6, 2017, https://churchsociety.org/blog/entry/serving the_truth_in_scandal, and "Jonathan Fletcher," Church Society, July 1, 2019, https://churchsociety.org/blog/entry/ jonathan_fletcher.

223 Facebook communication with Rev. Dr. Lee Gatiss, July 28, 2020.

224 James Mendelsohn, "Lee Gatiss, the 2015 JAEC Facebook Page, and Stephen Sizer," Large Blue Footballs, February 14, 2021, https://largebluefootballs.wordpress.com/2021/02/14/lee-gatiss-the-2015-jaec-facebook-page-andstephen-sizer/; and idem, "John Telford, the 2015 JAEC Facebook Page, and Stephen Sizer," Large Blue Footballs, February 28, 2021, https://largebluefootballs.wordpress.com/2021/02/28/john-telford-the-2015-jaec-facebookpage-and-stephen-sizer/. Dr. Gatiss contributed to the discussion by "liking" a comment that defended Dr. Sizer. Given Dr. Gatiss's role as a moderator of that Facebook group, and his position as the Director of Church Society, his "like" carried weight. It indicated to group members which side of the debate he favored.

225 Gatiss, "Response."

226 Bernard Nicholas Howard and James Mendelsohn, "Church Society and Antisemitism: A Failure of Leadership," Nick Howard, November 12, 2020, https://nickhoward76.medium.com/church-society-and-antisemitism-a-failure-of-leadership-c6ccbfc2c7d7. At the time of writing, Church Society has not publicly responded to this article.

227 See Section 6, above.

228 See the discussion in Section 4, above.

229 Howard and Mendelsohn, "The Racism Within," section 4.

230 "Reach, Build, Send:This Year's Junior Anglican Evangelical Conference," Church Society, February 29, 2016, https:// web.archive.org/web/20210126023802/https://churchsociety.org/blog/entry/reach_build_send_this_years_ junior_anglican_evangelical_conference; at the time of writing this is the most recent mention of the JAEC Committee on Church Society's website. 
231 "Junior Anglican Evangelical Conference 2014," Church Society, https://churchsociety.org/resources/page/junior_ anglican_evangelical_conference_2014; "Junior Anglican Evangelical Conference 2017," Church Society, https:// churchsociety.org/resources/page/junior_anglican_evangelical_conference_2017; "JAEC 2018: The Gospel in the Parish," Church Society, April 12, 2018, https://churchsociety.org/blog/entry/jaec_2018_the_gospel_in_the_parish (all accessed January 26, 2021).

232 Dr. Vibert is also connected to Church Society via the Fellowship of Word and Spirit, an organization that he represents as a trustee, which merged with Church Society in 2018. "Fellowship of Word and Spirit," Register of Charities, search performed January 25, 2021, https://register-of-charities.charitycommission.gov.uk/charity-search/-/charity-details/293159/trustees; "A United Church Society Annual Meeting," Church Society, May 14, 2018, https://churchsociety.org/blog/entry/a_united_church_society_annual_meeting.

233 According to Dr. Gatiss, a member was removed from the Society after he expressed sympathy for White supremacism. Facebook communication, June 4, 2020.

234 Church Society, Podcast: Racism | Politics, YouTube video, June 1, 2020, https://www.youtube.com/watch?time_continue $=144 \& v=\_b R g o M \_7 L 5 Y \&$ feature $=e m b \_l o g o$, particularly 2:45 $-3: 15$ and 15:50-18:00.

235 Gatiss, "Response."

236 Ros Clarke, "The Autumn 2020 Edition of Crossway," Church Society, September 29, 2020, https://churchsociety. org/crossway/page/the_autumn_2020_edition_of_crossway/;CChurch Society, Crossway 157 (Autumn 2020). Nor had any Crossway articles addressed antisemitism during the previous five years-a period in which, in addition to the controversy over Dr. Sizer, Jeremy Corbyn had become leader of the Labour Party and antisemitism had been a prominent issue in both the 2017 and 2019 British General Elections.

237 Church Society, "Racism, Repentance, Revelation," YouTube video, February 8, 2021, https://youtu.be/xvn33fp0a08, 21:45-24:15.

238 Gatiss, "Response."

239 "Reform Archive," Church Society, accessed September 19, 2020, https://churchsociety.org/resources/page/ reform_archive.

240 James Mendelsohn, "IVP: Three Writers, Double Standards?" Large Blue Footballs, October 14, 2016, https:// largebluefootballs.wordpress.com/2016/10/14/ivp-three-writers-double-standards/; "John Bevan," "Inter-Varsity Press Withdraw Stephen Sizer's Books," Harry's Place, November 24, 2016, http://hurryupharry.net/2016/11/24/ inter-varsity-press-withdraw-stephen-sizers-books/.

241 "IVP Issues Statement about Peter O'Brien Plagiarism Issue," September 26, 2016, https://www.frontgatemedia. com/ivp-issues-statement-about-peter-obrien-plagiarism-issue/. The statement includes comments from InterVarsity Press (a US publisher) and Inter-Varsity Press (a British publisher). These are separate entities, but sometimes they publish the same authors — as was the case with Peter O'Brien and Stephen Sizer.

242 Caleb Woodbridge and Sue Halliday, "A Statement Regarding Steve Timmis," February 10, 2020, https://ivpbooks. com/blog/a-statement-regarding-steve-timmis.html.

243 Scottish Council of Jewish Communities, "SCoJeC Protests to Church of Scotland about Support for Hate-Linked Cleric," November 1, 2012, https://www.scojec.org/news/2012/12xi_cos/cos.html.

244 Howard and Mendelsohn, "The Racism Within."

245 Email (via website form) from author 2 to Evangelicals Now, June 20, 2020; email from author 2 to Rev. William Taylor, July 14, 2020; email from author 2 to lan Roberts, June 20, 2020; email from author 2 to Rev. Dr. Lee Gatiss, June 21, 2020; email from author 2 to Rev. Dr. Simon Vibert, June 21, 2020.

246 Our position here arguably resembles similar reasoning about Marx: Robert Fine, "Karl Marx and the Radical Critique of Antisemitism," Engage Journal 2 (2006), accessed 1 February 2021, https://engageonline.wordpress. com/2015/11/04/karl-marx-and-the-radical-critique-of-anti-semitism-robert-fine-engage-journal-issue2-may-2006/.

247 See, for example, Carson, The Gagging of God, 333-338; Steve Motyer, Your Father the Devil? A New Approach to John and "the Jews" (Carlisle: Paternoster, 1997); and idem, Antisemitism and the New Testament (Cambridge: Grove Books, 2002). Motyer's Your Father the Devil? is favorably reviewed in the widely read conservative evangelical journal Themelios: David Wenham, "Your Father the Devil? A New Approach to John and 'the Jews," Themelios 24, no. 3, https://www.thegospelcoalition.org/themelios/review/your-father-the-devil-a-new-approach- 
to-john-and-the-jews/.

248 For instance, Dr. Sizer uses Ephesians 2 to justify his opposition to Israel's security barrier, likening the Israeli leaders who erected it to the first-century Jewish leaders whose desire to uphold the temple's purity laws led to the arrest of the apostle Paul. Sizer, Zion's Christian Soldiers?,69-70. We cannot think of any other mainstream conservative evangelical leader who would apply Ephesians 2 in this way. Dr. Sizer has also claimed, "The Jewish people are not God's chosen people, and I say that emphatically. As a race they never were God's chosen people." Stephen Sizer, "'Zion's Christian Soldiers': What Is the Biblical Link between the Church and Israel?" address to the Yorkshire Reformed Ministers Fraternal, April 28, 2014. Many evangelicals would say that belonging to God's people is ultimately contingent on repentance and faith (an idea arguably derived from the Tanakh itself, for example, 1 Kings 19:18), but we cannot think of any other mainstream conservative evangelical leader who would on that basis join Dr. Sizer in denying the chosen-ness of the Jewish people altogether.

249 See the first of the two analogies in section 8 (b).

250 Freeman, "After Wiley."

251 Hirsh, Contemporary Left Antisemitism, 1.

252 See Section 8 (b), above. 